\title{
CRIMES NO COMÉRCIO INTERNACIONAL: ANÁLISES SOCIOECONÔMICAS IMPACTANTES NO BRASIL
}

\author{
Jéssica Louise Bezerra Varela \\ Graduada em Tecnologia em Comércio Exterior pelo Instituto Federal de Educação, \\ Ciência e Tecnologia do Rio Grande do Norte, IFRN. E-mail: \\ jessicaa.louise@hotmail.com \\ Elisângela Cabral de Meireles \\ Graduada em Ciências Econômicas-UFRN, esp. em Economia Regional, Comércio \\ Exterior e Globalização-UFRN, mestre em Administração (Gestão e Políticas Públicas) \\ UFRN , Professora do IFRN (Comércio Exterior e Economia) e Professora Orientadora da \\ Base de Pesquisa “Análise do Mercado Exportador do Rio Grande do Norte (IFRN). \\ E-mail- elisangela@cefetrn.br
}

\section{RESUMO}

O presente trabalho tem como objetivo avaliar os impactos socioeconômicos incidentes no Brasil devido à ocorrência de crimes no comércio internacional. Com esse recorte pretende-se, primeiramente, identificar os crimes contra o comércio internacional que interferem no âmbito econômico e social brasileiro, dentre os quais foram selecionados: contrabando, descaminho, pirataria, dumping e evasão de divisas. Em seguida, analisam-se os principais fatores que impulsionam a ocorrência desses ilícitos e são avaliadas as medidas preventivas e repressivas feitas por importantes organismos estatais e internacionais. Por fim, é apresentada a análise dos impactos gerados por esses delitos na sociedade e nas relações comerciais, especialmente no âmbito nacional. A metodologia utilizada neste estudo consistiu numa pesquisa exploratória descritiva feita através de livros, artigos científicos, monografias e sítios da Internet. Foram levantados também dados secundários junto a organismos estatais, bem como foram realizadas entrevistas com profissionais da área em discussão. Assim, ao analisar os aspectos teóricos e práticos, buscou-se destacar a importância do combate desses crimes, já que dificultam o desenvolvimento de um comércio internacional justo. Dentre os resultados obtidos, percebe-se que os crimes no comércio internacional geram enormes prejuízos socioeconômicos no país, ao passo que fomentam o desemprego, a criminalidade interna e transnacional, estimulam a corrupção, geram perda na arrecadação fiscal, prejudicam a indústria nacional devido à concorrência desleal causada pelas mercadorias ilegais e afetam diretamente a autonomia e soberania do país.

PALAVRAS-CHAVE: Comércio Internacional. Comércio Ilegal. Impactos socioeconômicos.

\begin{abstract}
This study seeks to evaluate the socioeconomic impacts acting in Brazil due to the occurring of crimes in international commerce. Under this scope, it intends to identify crimes in international commerce which interfere in Brazilian social and economic spheres, specifically contrabanding, smuggling goods, piracy, dumping and money laundering. Then, the most relevant factors which lead to the occurrence of this crimes are analyzed.
\end{abstract}


Preventive and repressive measures taken by relevant national and international organisms are also considered. Finally, an analysis on the consequences of these delicts, both on society and trade relations, is presented - concerning mainly national levels. The methodology used consists in a descriptive exploratory research done through books, scientific articles, monographies and internet sites. Secondary data is also searched among organisms and professionals of the area are interviewed. Both practical and theorical aspects are taken into count as a way to highlight the importance of combating once they interfere on the development of a fair commerce. It has been noticed among the results obtained that the crimes in international commerce generate enormous socioeconomic prejudice to the nation once they lead to corruption, fare collection loss, damage to the national industry caused by unfair competition of the illegal products as well as they affect the autonomy and sovereignty of the country.

KEY-WORDS: International Commerce. Illegal Commerce. Socioeconomic Impact. 


\section{CRIMES NO COMÉRCIO INTERNACIONAL: ANÁLISES SOCIOECONÔMICAS IMPACTANTES NO BRASIL}

\section{INTRODUÇÃO}

Os crimes no comércio internacional abrangem atividades ilegais praticadas por particulares, ou por nações, a fim de atender interesses próprios. Esses crimes são antigos e derivam dos famosos contrabandos na Antiguidade, em que existiam os conhecidos "mercados de ladrões". De acordo com as publicações examinadas para a consecução deste trabalho, o comércio ilegal é tido como um comércio que infringe regras, que as nações criam para proteger a sua economia e, por conseguinte a sua população, e quando não seguidas, acarretam prejuízos que incidem em toda a sociedade.

Estes crimes apresentam-se em oposição às boas práticas comerciais, já que não utilizam das prerrogativas existentes para o desenvolvimento comercial lícito e aceito internacionalmente. As relações comerciais de caráter global têm atualmente a possibilidade de suprir a demanda mundial por produtos e serviços. No entanto, com o incremento do comércio ilícito, a oferta de produtos legais está estagnada, enquanto que a procura por bens e serviços só cresce. Isto resulta, como num círculo vicioso, em novas práticas ilícitas e desleais no comércio internacional, causando impactos tanto na sociedade quanto na economia nacional e global.

Tendo em vista essa discussão e os aspectos intervenientes apresentados, surge espaço para a seguinte problemática de pesquisa: quais os efeitos sociais e econômicos impactantes no Brasil gerados pelos crimes no comércio internacional?

A partir disso, tem-se que o presente trabalho analisa os impactos socioeconômicos causados pelos crimes no comércio internacional, perpassando pela evolução e dinâmica deste no cenário global. Uma das principais causas gerais do qual derivam esses crimes é a globalização, apontada por muitos autores como a grande desencadeadora desse processo. A globalização, juntamente com a expansão tecnológica, a ampliação dos mercados e a maciça transferência de produtos, viabilizaram o desenvolvimento, tanto do comércio lícito quanto do comércio ilícito, e conseqüentemente, dos crimes no comércio internacional, que estão reconfigurando a economia mundial e introduzindo novos atores no poder e na política global.

Desta forma, o trabalho destacará alguns crimes nesse âmbito, que consistem em: dumping, contrabando, descaminho, evasão de divisas e pirataria. Mostrará também as medidas preventivas e repressoras adotadas pelos governos e examinará a participação de órgãos públicos, bem como de organizações não-governamentais e organismos internacionais na repressão a estas práticas comerciais ilícitas. Para tanto, verifica-se também a ocorrência desses crimes no Brasil, bem como se analisa os principais fatores que geram e fomentam estas práticas, para, por fim, serem avaliados os impactos causados por esses atos ilícitos na sociedade e nas relações comerciais.

A temática de crimes no comércio internacional, até então pouco explorada pelos pesquisadores, é de suma importância para toda a sociedade, visto que os seus efeitos repercutem diretamente na qualidade de vida de todo cidadão. Há também de se destacar o fato de que estes crimes são atualmente conhecidos como os principais problemas de 
entraves comerciais entre os países, sendo, por exemplo, a pirataria conhecida como o delito do século. Isto mostra a influência dos efeitos destes ilícitos sobre a comunidade em geral, demandando urgentemente ações repressoras e punitivas para conter o seu avanço.

No que diz respeito ao âmbito acadêmico, percebe-se que esta temática tem ainda uma gama de assuntos a serem abordados e discutidos. Desta forma, esta pesquisa visa contribuir também para a unidade acadêmica e para os profissionais que atuem no comércio internacional, ao analisar as medidas repressivas e preventivas adotadas para a coibição desses crimes, além de compilar dados estatísticos sobre as suas ocorrências. Isto poderá facilitar os trabalhos desenvolvidos por essas instituições, ao passo que o trabalho demonstrará, de forma compilada, as causas e efeitos destes crimes, auxiliando no exercício das funções desses profissionais.

Para a pesquisadora integrante, a produção deste trabalho busca fornecer respostas a grandes inquietações, tanto pessoais quanto acadêmicas, sobre os efeitos gerados na sociedade, cujas repercussões influenciam diretamente no cotidiano das pessoas e nas relações comerciais entre os países.

A metodologia a ser utilizada neste estudo consiste numa pesquisa exploratória descritiva feita por meio de livros, artigos científicos, monografias e através de sítios da Internet. Assim, serão feitas análises no trabalho a partir desses dados secundários pesquisados. De acordo com Gil (2002), as pesquisas exploratórias têm o objetivo de proporcionar ao leitor mais familiaridade com o problema a ser abordado. Para tanto, utiliza-se de estudos bibliográficos, entrevistas com pessoas da área, bem como a análise de exemplos que facilitem a compreensão do leitor. E segundo o mesmo autor, a pesquisa descritiva tem o condão de descrever as características de determinado grupo ou temática a ser estudada.

Com isso, serão também levantados dados secundários junto a organismos estatais ou não, bem como serão realizadas entrevistas com profissionais da área em discussão. Estes dados secundários obtidos deverão ser analisados à luz das fontes bibliográficas estudadas para o trabalho, e quando necessário, será utilizada a estatística descritiva para a discussão de valores obtidos, para se alcançar uma análise mais detalhada e conclusiva sobre os números apresentados.

Assim, este estudo visa mostrar para a sociedade, tanto leigos quanto profissionais que atuem na área, as implicações sociais e econômicas da prática de atos ilícitos no comércio internacional. Este trabalho pretende, também, informar as pessoas acerca dos efeitos gerados, tais como o financiamento do crime organizado e o aumento do índice de desemprego, além de destacar a urgência na adoção de medidas para coibir a prática destes delitos comerciais.

\section{COMÉRCIO INTERNACIONAL: DINÂMICA, EVOLUÇÃO E IMPACTOS}

O comércio internacional vem ganhando agilidade ao longo dos anos, já que entraves foram sendo suprimidos, tais como algumas barreiras alfandegárias, a exemplo de alguns tributos, e determinados impostos e taxas. A tendência global é a de que cada vez mais os países se relacionem entre si, e que cresçam as comercializações entre as empresas. (BARBOSA, 2004) 
Neste sentido, abre-se espaço para a análise do comércio internacional, especialmente no que tange as suas perspectivas, evolução e características.

\title{
COMÉRCIO INTERNACIONAL
}

O comércio internacional vem se modificando radicalmente ao longo dos anos, já que, atualmente, impera a nova ordem global, que traz consigo a desregulamentação mercantil e o pleno acesso aos mercados. Desta forma, destaca-se um sistema comercial internacional mais ágil, dinâmico, objetivando suprir a demanda mundial por produtos e serviços, fomentando a economia global e gerando condições de desenvolvimento da sociedade. Neste sentido, Barbosa (2004, p. 22) enfatiza que o comércio internacional têm:

\begin{abstract}
Metas, que em tese, somente poderão ser atingidas a partir da configuração de um hábil sistema organizativo e disciplinador do comércio internacional. Sistema esse capaz de eliminar ou ao menos prevenir o aparecimento e ou recrudescimento de focos protecionistas, de práticas discriminatórias, de condutas políticas, econômicas e concorrenciais abusivas, controversas, ambíguas, e de caráter muitas vezes retaliativo e preconceituoso insistentemente ainda embutidas por detrás das fachadas que abrigam o desenrolar das relações de troca globais.
\end{abstract}

Essas novas pretensões do comércio mundial ensejam a necessidade de uma normatização internacional, de caráter multilateral e supranacional, que discipline as relações comerciais ao definir regras a serem utilizadas durante a condução das negociações.

Destaca-se também a necessidade de cooperação internacional, para que se faça uso de uma assistência mútua entre os países, a fim de solucionar de forma mais rápida e eficaz possíveis entraves no comércio mundial. Esta assistência deverá ser instituída com a assinatura de protocolos e convenções, a fim de que sejam protegidos preceitos comerciais básicos, além de tutelar a segurança e democracia humana nas relações comerciais internacionais.

No que diz respeito aos entraves comerciais devido às ações de grupos criminosos transnacionais, o vice secretário-geral assistente da Divisão Criminal do Departamento de Justiça dos Estados Unidos, Swartz (2001, p.10) afirma que:

\begin{abstract}
A ameaça complexa e crescente do crime internacional exige reação de múltiplas facetas. A reação do Departamento de Justiça dos Estados Unidos ao crime internacional divide-se em três partes: investigação e processo da atividade criminosa; criação de uma rede de acordos internacionais para possibilitar a cooperação na luta contra o crime transnacional; e programas de assistência técnica e treinamento para países estrangeiros que estejam lutando para aprimorar sua infra-esstrutura legal e capacidades de execução da lei.
\end{abstract}

Desta forma, observa-se que a nova ordem mundial é a de união, reunindo esforços e transmitindo conhecimento para o restante dos países, para que estes também consigam combater os entraves no comércio internacional, como o dos crimes transnacionais anteriormente citados. Isto é de grande importância, já que por se tratar de um problema global, só se obterão resultados satisfatórios quanto à melhoria do comércio internacional, se houver um esforço conjunto de todos os países. 


\title{
EVOLUÇÃO DO COMÉRCIO INTERNACIONAL
}

Ao longo da história, o comércio internacional apareceu como peça fundamental no desenvolvimento das relações humanas. Os primeiros registros mostram civilizações isoladas, cada qual com a sua própria cultura, e auto-suficientes em todos os aspectos, desde o econômico ao social, ao passo que não tinham interligações entre si. Destacam-se, assim, as civilizações Asteca, Maia, Inca, bem como outras economias autônomas como Gênova, Veneza, Milão e Florença, na Europa, e a China, Indochina, Malásia e Índia. Quanto a isto, afirma-se que:

\begin{abstract}
Durante milhares de anos elas desconheceram-se e nem imaginavam que algum dia poderiam estabelecer relações significativas. Se é certo que em suas bordas haviam escambo ou comércio, eles eram insignificantes. Portanto, numa longa perspectiva, pode-se dizer que a internacionalização do comércio e a aproximação das culturas é um fenômeno recentíssimo, datando dos últimos cinco séculos, apenas $10 \%$ do tempo da história até agora conhecida. (SCHILLING, 2010)
\end{abstract}

Posteriormente, durante a Idade Média, que durou do século V até o século XV, prevaleceu o sistema de feudalismo. Este sistema caracterizava-se pela formação de feudos (propriedades rurais) que visavam também à auto-suficiência, ao produzir praticamente tudo o que necessitavam para sobreviver. Desta forma, as atividades comerciais entre os feudos se restringiam a raríssimas trocas de produtos faltosos nestas propriedades, fenômeno que ocorria geralmente em feiras e em aldeias próximas.

Há de se destacar também, logo em seguida, o renascimento comercial das Cruzadas, que impulsionou o revigoramento comercial durante a Idade Média, principalmente com o restabelecimento da navegação pelo Mar Mediterrâneo, que foi reaberto e possibilitou que as mercadorias fossem melhor distribuídas pela Europa. Segundo Luz (2006), isto se deve ao incremento populacional, resultado do fim das invasões bárbaras, que fez com que as cidades fossem povoadas novamente.

Com o final da Idade Média, surge a Idade Moderna, período que abrange desde o Século XV até meados do Século XVIII. A Idade Moderna firmou-se inicialmente com a consolidação de uma nova classe social, a burguesia. Os burgueses, que já existiam desde a Idade Média e eram os responsáveis pelo sistema de trocas entre os feudos, reaparecem neste período como uma classe que centralizava o poder comercial. Os reis, que pretendiam reestabelecer o poderio político que perdera para os feudos, aliaram-se a burguesia e passaram a estimular o comércio. Assim, surge o Estado Moderno, que incitou as relações comerciais e financiou boa parte das Grandes Navegações.

Desta forma, inicia-se o período do mercantilismo, que foi caracterizado pelo teórico John Locke como sendo um período em que a quantidade de metais preciosos de um Estado definiria a sua situação econômica. Quanto a isto, Locke afirmava que quanto mais metais preciosos entrassem no Estado, os produtos importados sairiam mais baratos, pois o resto dos países estaria empobrecido e o Estado venderia para os demais produtos mais caros, sendo uma situação enriquecedora para ele. Em contrapartida, Locke afirmava que a saída de metais preciosos, que ocorria a partir da importação de produtos, diminuiria a quantidade de metais preciosos no país e prejudicaria a sua economia. Assim, segundo Luz (2006, p.17): "quem importasse mercadorias estaria colaborando para gerar a falência do país mesmo que gastasse um único grama de ouro", já que gastar metais preciosos se tornaria um ciclo vicioso e que culminaria com o euxarimento das reservas. 
Como características do período mercantilista, destacam-se também o protecionismo e a concomitante colonização de locais até então desconhecidos para o mundo. Sob a mesma premissa descrita no parágrafo anterior, em que a importação era taxada como prejudicial nas relações comerciais daquela época, a metrópole abominou a importação de produtos para o seu Estado e, em oposição, intensificou a exportação de produtos para as suas colônias, a fim de arrecadar mais metais preciosos.

Em seguida, durante o século XVIII, surge uma teria elaborada por Adam Smith, chamada de Teoria das Vantagens Absolutas, que vai esbarrar com os preceitos pregados pelo mercantilismo. Sobre isto, Luz (2006, p.18) discorre que:

Adam Smith, também atacava o protecionismo, dizendo que o país ganha mais se importar as mercadorias que produz de forma ineficiente. E concentrando energias naquilo que se produz com maior eficiência.

Desta forma, Adam Smith afirmava que o país deveria investir na exportação de produtos em que possuísse maior habilidade em fabricar, devendo, portanto, importar aqueles que fossem mais custosos ao país. Assim, as importações e exportações de um país deveriam ser moldadas a fim de beneficiá-lo, dinamizando, assim, mais uma vez, o comércio internacional entre os países. Como resultado, surge o Liberalismo, que pregava o não intervencionismo estatal na economia, incitando uma nova configuração comercial em âmbito mundial, que foi analisada por diversos teóricos ao longo da História, como David Ricardo (que criou a Teoria das Vantagens Comparativas), John Stuart Mill (que elaborou a Teoria da Demanda Recíproca), Heckscher-Ohlin (que criaram o Teorema HeckscherOhlin, também chamado de Teoria da Dotação de Fatores), dentre outros ${ }^{1}$ (LUZ, 2006).

Observa-se que havia no plano teórico econômico vigente até então, que a lógica das comercializações entre os países deveria ser de ganha-perde, em que uma nação ganha em detrimento do prejuízo de outra. Esta mentalidade era notada até meados do século XIX, em que se passou a defender que a lógica das comercializações entre os países era de ganha-ganha, ou seja, que ambos os lados referentes à negociação deveriam obter lucros e vantagens daquela transação. Neste novo cenário é inserida a globalização, que irá modificar os rumos da economia mundial. Há de se destacar também, que os crimes no comércio internacional influenciam de maneira decisiva nesta lógica de ganha-ganha do comércio internacional, visto que nestes casos haveria a lógica ganha-perde, já que um grupo específico ganha em relação à outro, que sai prejudicado dessa relação.

Assim, em momento posterior, destaca-se o período da globalização, que modernamente diz respeito ao período de integração econômica sob a égide do neoliberalismo, caracterizada pela desregulamentação dos mercados. Muitos teóricos criticam esta posição, ao afirmar que a globalização iniciou em meados do século XV. No entanto, este trabalho

\footnotetext{
${ }^{1}$ Acerca dessas teorias e autores, pode-se perceber que a Teoria das Vantagens Comparativas afirma que o país deve se basear em suas fraquezas na produção de determinados bens, analisando, em outro País, o que estaria disposto a dar em troca por esses bens, obtendo, assim, vantagem no livre comércio. Quanto à Teoria da Demanda Recíproca, conclui-se que há a necessidade de aferição da demanda de determinados produtos de um País com quem outro País deva comercializar, bem como a observação da demanda de produtos neste outro País, para decidir da melhor maneira como se deva proceder às negociações. E no que diz respeito à Teoria das Vantagens Comparativas, conclui-se que não há a negação da validade da Teoria das Vantagens Absolutas, já que afirma que cada país deva se especializar e exportar os bens que utilizem o fator de produção abundante de maneira mais intensiva, dentre os fatores: mão-de-obra, capital, tecnologia e recursos naturais. (LUZ, 2010)
} 
utilizará o termo globalização em seu sentido moderno, a fim de ilustrar um período que se inicia no século XX, com os avanços tecnológicos.

A globalização fez um novo arranjo dos Estados, os apresentado, agora, de maneira interconectada e independente. Observa-se que os assuntos tratados anteriormente no âmbito interno, como meio ambiente, segurança e economia política nacional, são atualmente discutidos internacionalmente, já que os impactos gerados por qualquer mudança nesses quesitos é de ordem global, afetando as relações internacionais entre os países.

Desta forma, surgem questões globalizadas que influenciam a vida dos cidadãos em todo o mundo, demandando, assim, esforços dos Estados para alcançar objetivos comuns necessários para a manutenção da ordem econômica e social mundial. Dentre esses assuntos, surgem discussões acerca dos crimes internacionais, com o conseqüente surgimento de medidas políticas, econômicas e sociais de combate à pirataria, contrabando de mercadorias, descaminho e dumping, dentre outras práticas ilícitas internacionais facilitadas pela globalização.

A globalização influenciou também diretamente no desenvolvimento da comunicação e cultura, que foram incrementadas pelo surgimento de novas ferramentas como o e-mail, a transmissão por satélite e as redes mundiais de televisão, que transmitem notícias em tempo real para todo o mundo.

Portanto, o comércio internacional vem paulatinamente se desenvolvendo ao longo dos tempos, deixando de ser marcado pelo protecionismo nacional e passando a ser influenciado pelas aberturas de mercados, pelo seu fácil acesso, e consequentemente pela globalização. De acordo com Barbosa (2004), a evolução do comércio internacional pode ser observada atualmente pelo incremento das exportações mundiais, que saltaram de uma taxa média de $4,1 \%$, de 1980 a 1990, para uma taxa média de 5,4\%, no período entre 1990 e 1999.

Assim, observa-se uma maior produção em todas as regiões do mundo, em que a demanda de um país pode ser suprida pela oferta de produtos de outro, intensificando, dessa forma, os regimes internacionais de troca. Nesse contexto, se faz necessário a regulamentação dessas atividades no comércio internacional, a fim de que se protejam interesses nacionais e de que sejam evitados ou penalizados os crimes no comércio internacional.

\section{COMÉRCIO INTERNACIONAL NO BRASIL}

O Brasil passou, ao longo de sua história, por ciclos econômicos marcantes que determinaram a economia, cultura e política do país, como o pau-brasil, a cana-de-açúcar, ouro e café. Há de se destacar que estes ciclos econômicos influenciaram diretamente no desenvolvimento social da população brasileira, que sofria mudanças em seu comportamento ao passo em que havia substituição de um ciclo por outro.

O ciclo econômico do pau-brasil iniciou-se com a descoberta do país pelos europeus, que passaram a explorar a atividade de extração do pau-brasil com o intuito de enviá-lo para a metrópole, pois esta árvore desprendia um pigmento avermelhado bastante apreciado no continente europeu. Os portugueses instalaram um sistema de sesmarias e instituíram 
também um sistema de trocas, em que negociavam com os índios para que fossem responsáveis pelo corte e carregamento da madeira em troca de objetos, prática conhecida como escambo.

Em momento posterior, destaca-se o ciclo econômico da cana-de-açúcar, que se iniciou em meados do século XVI. Quanto a este ciclo, Baer (2002, p.33) enfatiza que:

O primeiro produto de exportação importante do Brasil foi o açúcar. Seu cultivo foi introduzido aproximadamente em 1520. (...) A rápida expansão do cultivo e da exportação do açúcar logo se transformou na primeira de uma série de grandes ciclos de exportação primária, que iriam dominar o crescimento econômico do Brasil até o século XX.

O ciclo da cana-de-açúcar foi favorecido pela proximidade dos centros produtores, especialmente da Zona da Mata, com o continente europeu. Isto influenciava também diretamente no recebimento de mão-de-obra escrava proveniente da África. Esta mão-deobra foi escolhida devido à escassez de trabalhadores indígenas locais para trabalhar nas fazendas de açúcar, além de que trazer escravos africanos para o Brasil iria se tornar num negócio bastante lucrativo.

As exportações de cana-de-açúcar cresceram exponencialmente ao longo do tempo, visto que havia grande quantidade de terra disponível para o cultivo da cana-de-açúcar e havia o crescimento na quantidade de escravos. Neste sentido, Baer (2002) afirma que este negócio trouxe lucros especialmente para os "fazendeiros e aqueles envolvidos na exportação, financiamento, expedição e comércio de escravos". Segundo Baer (2002), os comerciantes também tiveram lucros com as importações, já que a colônia era dependente de produtos manufaturados provenientes da metrópole, bem como de alguns gêneros alimentícios.

Por volta do século XVII, destaca-se o ciclo econômico da mineração, em que o ouro foi o principal minério extraído. A extração deste minério dinamizou a sociedade local, com a chegada de grande número de migrantes provenientes do todas as partes do país. Desta forma, surgiram muitas cidades próximas aos centros de extração, que serviram como ponto de apoio aos extrativistas, além de ser utilizada como centro de serviços, principalmente com o surgimento dos setores artesanais e dos grupos bancários privados provenientes desta atividade.

Após o ciclo do ouro, especialmente no início do século XIX, observa-se um novo momento da economia brasileira, com o estabelecimento de um novo ciclo econômico, o café. Quanto a este século, Baer (2002, p. 38) afirma que:

Durante o século XIX, o Brasil adaptou-se facilmente à ordem econômica controladora da Grã-Bretanha, que se tornou o núcleo do centro industrial no mundo, trocando seus produtos manufaturados por alimentos e matérias-primas no exterior, ou seja, de países cujas economias eram completamente dependentes da exportação deles.

O café tornou-se produto básico de exportação brasileira de que dependia praticamente toda a economia do país. No que diz respeito à importação, destaca-se a maciça entrada de manufaturados ingleses no país e de capital estrangeiro, a fim de atender as demandas provenientes do café e da ordem econômica mundial então vigente. Como já adiantado 
anteriormente, o começo do século XIX foi marcado pelo ciclo do café, que viveu o seu auge nesta época, mas que teve início no século XVIII.

Tempos depois, o Brasil iniciou o seu desenvolvimento econômico que ocorreu após 1930, especialmente no Governo de Getúlio Vargas, período em que o Brasil alcançou elevadas taxas de crescimento econômico e desenvolveu grande parte de sua infra-estrutura. Em meados da década de 70 e 80, especialmente durante a Ditadura Militar e uma década após este período, o país passou por várias dificuldades econômicas, com o conseqüente aumento dos índices de inflação, a necessidade do arrocho salarial e o crescimento da dívida externa.

Com o advento do Plano Real, no Governo de Itamar Franco, iniciou-se a estabilização econômica do país, alcançando atualmente um respeito em âmbito mundial, o que facilita no fechamento de negócios com parceiros comerciais e na busca de potenciais mercados para comercializar.

Atualmente, o Brasil tem alianças comerciais com os principais mercados econômicos mundiais, como a União Européia, os Estados Unidos, o MERCOSUL e a República Popular da China. De acordo com dados publicados pela Organização Mundial do Comércio (OMC/WTO), divulgados pelo sítio do Centro Internacional de Negócios da Paraíba (2006), no ano de 2006 o Brasil ocupava o $23^{\circ}$ lugar no ranking de maior exportador mundial e $27^{\circ}$ no ranking de maior importador. Isto demonstra uma importante participação do Brasil no mercado internacional.

Assim, seguindo a tendência internacional, não era de se esperar comportamento diverso por parte do Governo Brasileiro, já que abarcado na tendência globalizadora, intensificou ainda mais relações comerciais com os outros países do mundo, aumentando a interdependência destes. Quanto a isto, destaca-se a observação de Hartung (2002, p.12):

\begin{abstract}
A participação no comércio internacional tem sido a chave para o sucesso e a prosperidade de empresas e países. Essa atuação não tem sido importante apenas para as nações ricas, mas também para as nações em desenvolvimento. Naturalmente, o governo brasileiro tem dado cada vez mais atenção ao comércio de produtos brasileiros com outros países.
\end{abstract}

No entanto, observa-se no decorrer da história brasileira, que o retorno da cultura exportadora, enraizada desde o período colonial, só aconteceu em meados dos anos 2000. Durante a década de 1980 até o início da década de 1990, o Brasil sofreu os resultados da crise do petróleo e da alta internacional dos juros, que aumentaram exponencialmente os valores do financiamento externo, além de que elevou consideravelmente a dívida contraída pelo país para custear os avanços econômicos obtidos com o período do Milagre Econômico (1968 a 1973). (BAER, 2002)

O Milagre Econômico ocorreu devido à disponibilidade externa de capital e o intuito dos governos militares de fazer com que o Brasil se tornasse uma grande potência, investindo pesadamente em infra-estrutura, nas indústrias de base $^{2}$ e em outros setores. No entanto, durante a década posterior, a chamada "Década Perdida" (1980), a economia brasileira passa por um período de dificuldades extremas, que resultam no desequilíbrio do balanço de pagamentos e ao descontrole da inflação, fatos que implicaram diretamente no bloqueio

\footnotetext{
${ }^{2}$ Há de se destacar que o crescimento da Indústria de Base brasileira começa no Governo de Getúlio Vargas. (Baer, 2002)
} 
de seu crescimento econômico, bem como no desenvolvimento de suas transações comerciais.

Posteriormente, em meados da década de 90, o Brasil avança na política neoliberalista, adotando medidas de privatização de empresas estatais e abrindo o mercado brasileiro para a entrada de produtos importados. Este último aspecto ocorreu devido a expressivas baixas da alíquota de importação na época, que provocou uma enxurrada de produtos estrangeiros no país, causando um aumento do desemprego, devido a falência de empresas, que não se viam em paridade para concorrer de forma justa com esses produtos, já que não tinham capital suficiente para investir em novas tecnologias para competir com as mercadorias estrangeiras.

Em seguida, durante o ano de 1994, acontece uma crise no México, devido a desvalorização de sua moeda em mais de 50\%, de acordo com Giambiagi (2000), irradiando uma nova crise financeira que afetou o mundo inteiro, inclusive o Brasil, no chamado "efeito tequila". Para tentar remediar a crise econômica já instaurada no país, o governo brasileiro decide mudar bruscamente a política cambial do país, abandonando as taxas de câmbio que eram relativamente rígidas e previsíveis. O resultado dessa nova política cambial mais flexível foi a de pequena melhora na economia, que ocorreu de forma superficial, já que houve uma desvalorização real das atividades realizadas no país, com a conseqüente manutenção das taxas de inflação, o que influenciava diretamente no mau desempenho da balança comercial brasileira. Quanto a este período, que ocorreu durante o implemento da moeda do Real, Souza (2003, p. 250) afirma que:

O Plano Real fundamentou-se na âncora cambial. No início do Plano, o real
começou valendo um dólar norte-americano, ficando, no entanto, flutuando no
intervalo de bandas fixas. Assim, entre julho de 1994 e março de 1995 , o câmbio
flutuou e o real valorizou-se, chegando a ser cotado em US\$ 0,84. A partir de
março de 1995 , o Governo adotou uma política de desvalorização do real em
torno de $7 \%$ ao ano. Essa política cambial foi fundamentada para conter os
preços e desindexar a economia, mas provocou desequilíbrio na balança
comercial, ao encarecer as exportações e baratear as importações. (...) O
superávit comercial de US\$10 bilhões em 1994 transformou-se em déficits
anuais sistemáticos, que em 1998 montou a US $\$ 4$ bilhões.

Este cenário só começou a ser alterado a partir do ano de 1998, já que o Brasil passou por outra crise econômica, o que demonstrou a importância de se adotar, novamente, taxas cambiais mais rígidas e, principalmente, esta nova crise demonstrou o essencial papel das exportações como forma de manter o saldo da balança comercial sempre positivo, possibilitando que a economia brasileira de recuperasse, como se pode observar com o Gráfico 1 a seguir: 


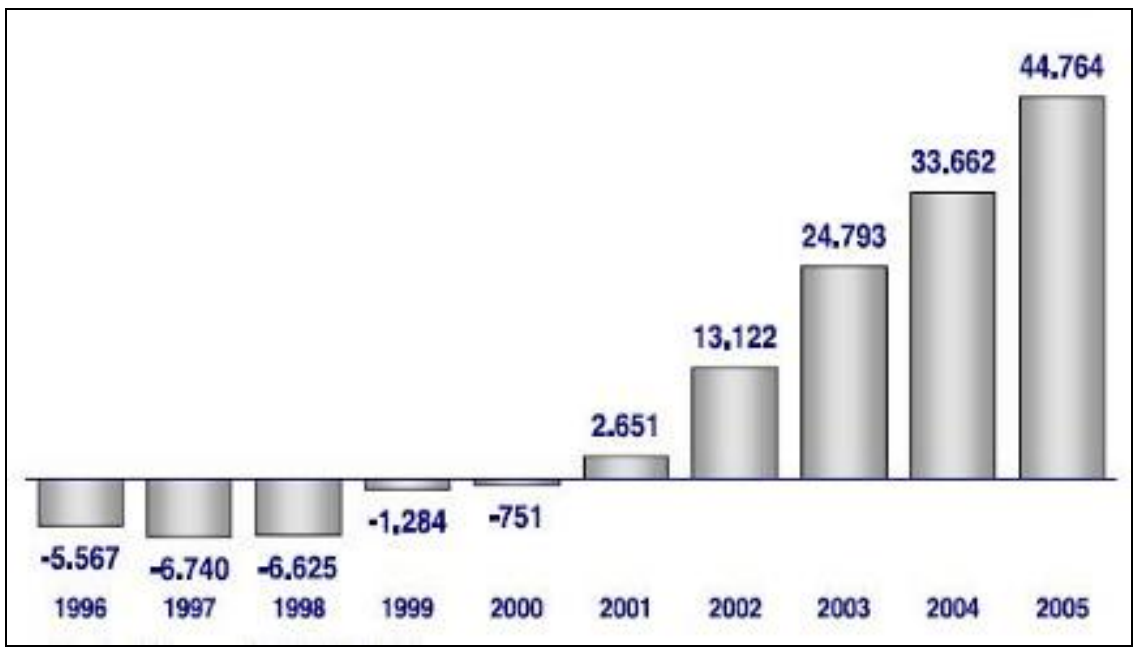

Gráfico 1: Evolução do Saldo Comercial 1996/2005. Fonte: SECEX/MDIC (2005)

A evolução do saldo da balança comercial brasileira é demonstrado no Gráfico 1 acima, que retrata os saldos negativos da balança comercial até meados de 1998, como já discutido anteriormente, e mostra a recuperação da balança comercial a partir do ano de 1999, com o exponencial crescimento durante os anos seguintes. O crescimento das exportações pode ser mais uma vez constatado com este outro gráfico:

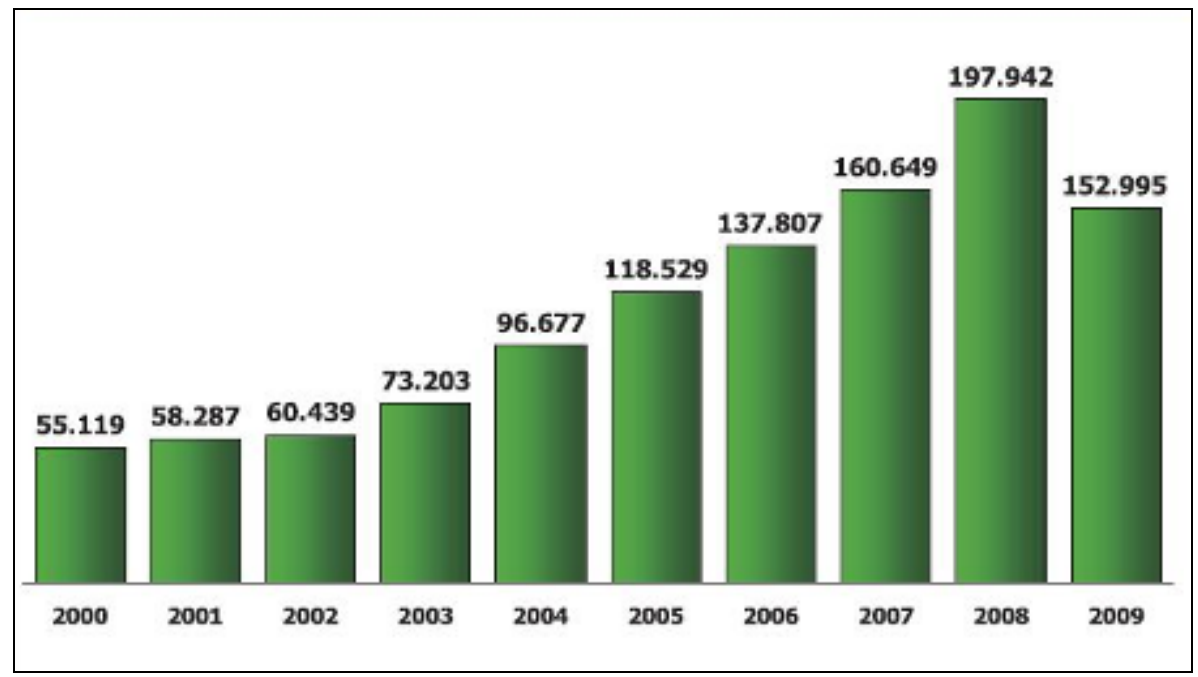

\section{Gráfico 2: Evolução das Exportações 2000/2009} Fonte: MDIC (2009)

Este outro gráfico mostra a consolidação da cultura exportadora do país nos últimos anos, enaltecendo tal postura como necessária para o desenvolvimento econômico do país, interferindo no aumento de empregabilidade do país, no aperfeiçoamento da indústria nacional e na melhoria das condições de vida da população.

No que tange o tema debatido neste trabalho, percebe-se que os crimes no comércio internacional interferem de maneira a provocar uma possível ingerência na balança comercial, resultando em implicações sociais no país que podem interferir nas exportações de produtos brasileiros, assunto este que será discutido mais adiante. 


\section{TIPIFICAÇÃO DOS CRIMES NO COMÉRCIO INTERNACIONAL}

Os crimes no comércio internacional compreendem práticas ilícitas e desleais praticadas por pessoas físicas ou jurídicas a fim de satisfazer interesses particulares. Segundo Toledo (1994, p. 80) tem-se que: "Substancialmente, o crime é um fato humano que lesa ou expõe a perigo bens jurídicos protegidos". Neste sentido, observa-se a importância do direito, especialmente de uma legislação específica, que normatize essas questões, a fim de coibir os crimes no comércio internacional.

Na mesma linha de pensamento, é importante destacarmos o que Naím (2006, p. 8) afirmou sobre comércio ilegal:

É um comércio que infringe as regras - leis, regulamentações, licenças, tarifas, embargos e todos os procedimentos de que as nações lançam mão a fim de organizar os negócios, proteger os cidadãos, aumentar as receitas e reforçar os códigos morais. Inclui compras e vendas que são rigorosamente ilegais em toda a parte e algumas que podem ser ilegais em alguns países, mas aceitas em outros.

Desta forma, as práticas ilícitas que serão retratadas neste trabalho serão: dumping, contrabando, descaminho, evasão de divisas e pirataria. No ordenamento jurídico brasileiro encontram-se tipificados os atos ilícitos que incorrem nestes crimes no comércio internacional.

\section{CONTRABANDO E DESCAMINHO}

O artigo 334 do Código Penal prevê os crimes de contrabando e descaminho, e suas respectivas sanções:

Art. 334 Importar ou exportar mercadoria proibida ou iludir, no todo ou em parte, o pagamento de direito ou imposto devido pela entrada, pela saída ou pelo consumo de mercadoria:

Pena - reclusão, de um a quatro anos.

Embora esses dois crimes apareçam num mesmo artigo, existem diferenças essenciais entre eles. O crime de contrabando figura-se na importação ou exportação de produtos proibidos, em que segundo Bonat (2004, p. 344): "Tal proibição vem ao encontro de proteção de interesses outros da sociedade e do Estado, como a saúde pública, a moral, a segurança nacional e, por vezes, a própria indústria nacional". Neste sentido, pode-se exemplificar contrabando como sendo a entrada proibida de medicamentos no país e a importação ou exportação ilegal de armas de fogo.

Já o crime de descaminho, configura-se num ilícito fiscal, ao contrário do contrabando, visto que objetiva iludir o pagamento dos impostos e cargas tributárias já previstas para a mercadoria, ou seja, tenta-se evitar o pagamento de direitos e impostos. De acordo com Mazur (2005):

O descaminho, ao contrário, constitui verdadeira fraude fiscal, fraude ao pagamento dos tributos aduaneiros, consubstanciada na ilusão, total ou parcial, de direito ou imposto devido pela entrada ou saída de mercadoria. É um ilícito de natureza tributária, no qual se verifica uma relação entre o Fisco e o contribuinte que não é verificada no contrabando. 
É notória a relação existente entre o crime de descaminho e o de evasão fiscal. Este último, em conceituação mais estrita, tem sua tipificação prevista no artigo $1^{\circ}$ e no $\operatorname{artigo} 2^{\circ}$ da Lei $\mathrm{n}^{\circ}$ 8.137/1990, intitulada de crimes contra a ordem tributária. A evasão fiscal é definida como o suprimento ou a redução de um tributo realizada através de ato ilícito, que de acordo com a lei destaca-se a omissão de informação, ou a declaração falsa às autoridades fazendárias; a fraude da fiscalização tributária, inserindo ou omitindo elementos; a falsificação ou alteração da nota fiscal, fatura, duplicata; e a falsa declaração sobre rendas ou fatos com o intuito de se eximir do pagamento do tributo.

O objetivo principal de se instituir a proibição de crimes de contrabando e descaminho é o de proteger as finanças do país, bem como tutelar outras áreas, como a saúde, a moral, a higiene, a ordem pública e a indústria nacional. Desta forma, o governo brasileiro instituiu o Programa Nacional de Combate ao Contrabando e ao Descaminho com o Decreto de $\mathrm{n}^{\mathrm{o}}$ 2.781/1998, no qual o seu primeiro artigo normatiza que:

\begin{abstract}
Art. 1 Fica instituído o Programa Nacional de Combate ao Contrabando e ao Descaminho, destinado a criar condições para a realização conjunta de tarefas e atividades, pela Secretaria da Receita Federal do Ministério da Fazenda e pelo Departamento de Polícia Federal do Ministério da Justiça, relativas à prevenção e repressão dos ilícitos penais e administrativos referentes à importação e exportação de bens.
\end{abstract}

Assim, o Governo Brasileiro mostra o importante papel da Receita Federal, do Ministério da Fazenda e da Polícia Federal para combater e prevenir os crimes de contrabando e descaminho. No entanto, não se pode deixar de lado o papel da sociedade em não aceitar a livre ocorrência desses crimes, se conscientizando de que a entrada desses produtos, embora pareça muito tentadora devido ao preço baixíssimo, prejudica as indústrias nacionais, bem como alimenta o mercado ilegal no Brasil.

No que se refere aos principais pontos de entrada terrestre de produtos contrabandeados no país, destaca-se Foz do Iguaçu. Em Foz do Iguaçu/PR, especialmente na Ponte da Amizade que liga o país ao Paraguai, há uma intensa atividade contrabandista que dinamiza toda a região em volta dela. Assim, produtos não autorizados entram de maneira corriqueira no país por meio desta fronteira, prejudicando não somente a arrecadação de impostos, que nesse caso não existe, e a indústria local, mas também a saúde e segurança dos consumidores que irão utilizar este produto. Isto se deve ao fato de não haver nenhuma certificação de qualidade desses produtos por parte dos órgãos fiscalizadores, como o Instituto Nacional de Metrologia Normalização e Qualidade Industrial (Inmetro), e Agência Nacional de Vigilância Sanitária (ANVISA).

Com relação à entrada nos aeroportos e portos brasileiros de produtos contrabandeados e que sofrem descaminho, nota-se que estas atividades são facilitadas pelo enquadramento destes produtos no canal verde. Segundo Franca (2008), não há um estudo que determine o valor correto das mercadorias que entram por esse canal, mas ele acredita que o valor se aproxime de $80 \%$ do total das mercadorias importadas. De acordo com o mesmo autor, não há pretensão de se abolir o canal verde, o que implicaria na fiscalização de todas as mercadorias que entram no país, mas existe a intenção de se escolher melhor a gama de produtos a serem introduzidos no país por esse canal. Esta nova análise determinará as empresas que serão "privilegiadas" por esse sistema criado pelo Siscomex (Sistema Integrado de Comércio Exterior) para facilitar as comercializações, já que a importação 
selecionada para o canal verde é desembaraçada automaticamente sem qualquer verificação.

De acordo com dados obtidos no sítio da SINDRECEITA (Sindicato Nacional da Carreira Auditoria da Receita Federal do Brasil), nos últimos 11 meses, a Receita Federal apreendeu o equivalente a setecentos e cinquenta milhões de reais ( $\mathrm{R} \$ 750$ milhões) de mercadorias no país. Além destas mercadorias, foram apreendidos também sete mil veículos que serviam como meio de transporte de produtos contrabandeados, sendo a maioria proveniente da região brasileira que faz fronteira com o Paraguai.

\title{
EVASÃO DE DIVISAS
}

No que diz respeito ao crime de evasão de divisas no comércio internacional, destaca-se a sua previsão como ilícito penal no artigo 22 da Lei $\mathrm{n}^{0} 7.492 / 1986$, que define os crimes contra o sistema financeiro nacional, e dá outras providências. Com a comprovação deste crime, ou seja, se uma pessoa efetuar operação de câmbio não autorizada, com o fim de promover evasão de divisas do País, este infrator é penalizado com reclusão que varia de dois a seis anos, estando também sujeito a multa. Assim, genericamente, a evasão de divisas consiste na remessa não autorizada de capital para o exterior, sem a devida declaração e a conseqüente arrecadação de impostos.

A título ilustrativo, pode-se definir o crime de evasão de divisas de acordo com o que afirma Peruchin (2006):

\begin{abstract}
A evasão de divisas, portanto, é a remessa de títulos ou ativos financeiros, de maneira clandestina, retirando-os da contabilidade e controle exercidos pelo BACEN. Essa remessa efetua-se por meio do repasse das divisas que integram as posições das instituições financeiras públicas ou privadas residentes no País, não obedecendo as regras administrativas editadas pelo BACEN, com a justificativa do abalo às reservas cambiais nacionais, se for alto o volume dos valores envolvidos. Essa operação ocorre, por exemplo, através da transferência de divisas por uma pessoa física ou jurídica (ou instituição financeira pública ou privada) com domicílio fiscal no País, para uma pessoa física ou jurídica com domicílio fiscal fora do Brasil. Isso acarretaria diminuição dos estoques de moedas estrangeiras de que dispõe a nação.
\end{abstract}

Nas comercializações internacionais, a evasão de divisas se dá com o subfaturamento das exportações e das importações. Este crime é corriqueiramente praticado por empresas multinacionais, bem como importadores e exportadores que transferem para paraísos fiscais parte do resultado obtido com as práticas criminosas. Quanto a isto, a Receita Federal, a fim de fiscalizar e punir estes criminosos, instituiu uma Delegacia especializada para combater os crimes de evasão de divisas. Através da Lei no 9.430/1996, este órgão federal criou os chamados "preços de transferência", presentes nos artigos 240 a 245 do Regulamento de Imposto de Renda, que são padronizados e servem como parâmetro para se analisar a fiscalização dos valores incidentes nas comercializações. De acordo com o site da Receita Federal, o termo "preço de transferência" significa o valor utilizado na compra e venda de bens, direitos e serviços entre partes relacionadas.

O preço-parâmetro das comercializações é apurado por meio dos métodos de preços de transferência presentes na legislação brasileira, que servirão de referência na comparação entre o preço-parâmetro e o que foi efetivamente praticado pela empresa. Caso o preço 
comercializado tenha valor muito diferente do preço-parâmetro, o contribuinte deverá pagar parte de seu lucro que lhe é devido.

Em aspecto prático, o crime de evasão de divisas para o exterior se dá com a remessa de capital não autorizada e, conseqüentemente, não declarada para o exterior, oriundo de atividades ilícitas ou aquelas legalizadas, mas não tributas de acordo com a legislação brasileira. Desta forma, não é proibida a remessa de capitais por pessoas que tenham declarado corretamente o Imposto de Renda das Pessoas Físicas e das Pessoas Jurídicas, e cujas remessas sejam efetuadas por instituições financeiras autorizadas pelo Banco Central.

A Figura 1 abaixo retrata, de maneira simplificada, umas das rotas utilizadas para a consecução do crime de evasão de divisas. Essa rota é aqui apresentada como um exemplo demonstrativo do grande esquema de evasão de divisas, que neste caso, compreendeu entre os anos de 1996 e 1999, no esquema conhecido como o "escândalo do Banestado". Esta rota mostra que o dinheiro proveniente do Brasil vai para o Paraguai e Uruguai através de contas da CC-5 (Carta-Circular 5), em nome de laranjas ${ }^{4}$ selecionados por doleiros ${ }^{5}$. Estas operações feitas são de valores abaixo de $\mathrm{R} \$ 10$ mil, já que operações acima deste limite tem de ser formalmente comunicadas ao Banco Central. Em seguida, o dinheiro sai das contas paraguaias e uruguaias em direção a bancos norte-americanos e, posteriormente, a empresas de fachada em paraísos fiscais, como a Suíça e as Ilhas Cayman. Em momento posterior, o dinheiro volta para o Brasil em transações ilegais que caem diretamente na conta dos brasileiros interessados, sob o disfarce de renda proveniente de investimento no exterior.

\footnotetext{
${ }^{3} \mathrm{O}$ escândalo do Banestado envolveu remessas ilegais de divisas, pelo sistema financeiro público brasileiro, para o exterior, na segunda metade da década de 1990. Ocorreu uma investigação federal e a instauração de uma Comissão Parlamentar de Inquérito em 2003. Pelo esquema do Banestado, foram enviados um total de US\$ 19 bilhões ilegalmente para os Estados Unidos da América. As autoridades estadunidenses conseguiram posteriormente recuperar US\$ 17 milhões, que foram devolvidos ao Brasil (WIKIPEDIA, 2010)

${ }^{4}$ Indivíduo, nem sempre ingênuo, cujo nome é utilizado por outro na prática de diversas formas de fraudes financeiras e comerciais, com a finalidade de escapar do fisco ou aplicar dinheiro de origem ilícita; testade-ferro. (HOUAISS, 2001)

${ }^{5}$ Que ou quem negocia dólares norte-americanos no mercado paralelo (HOUAISS, 2001).
} 


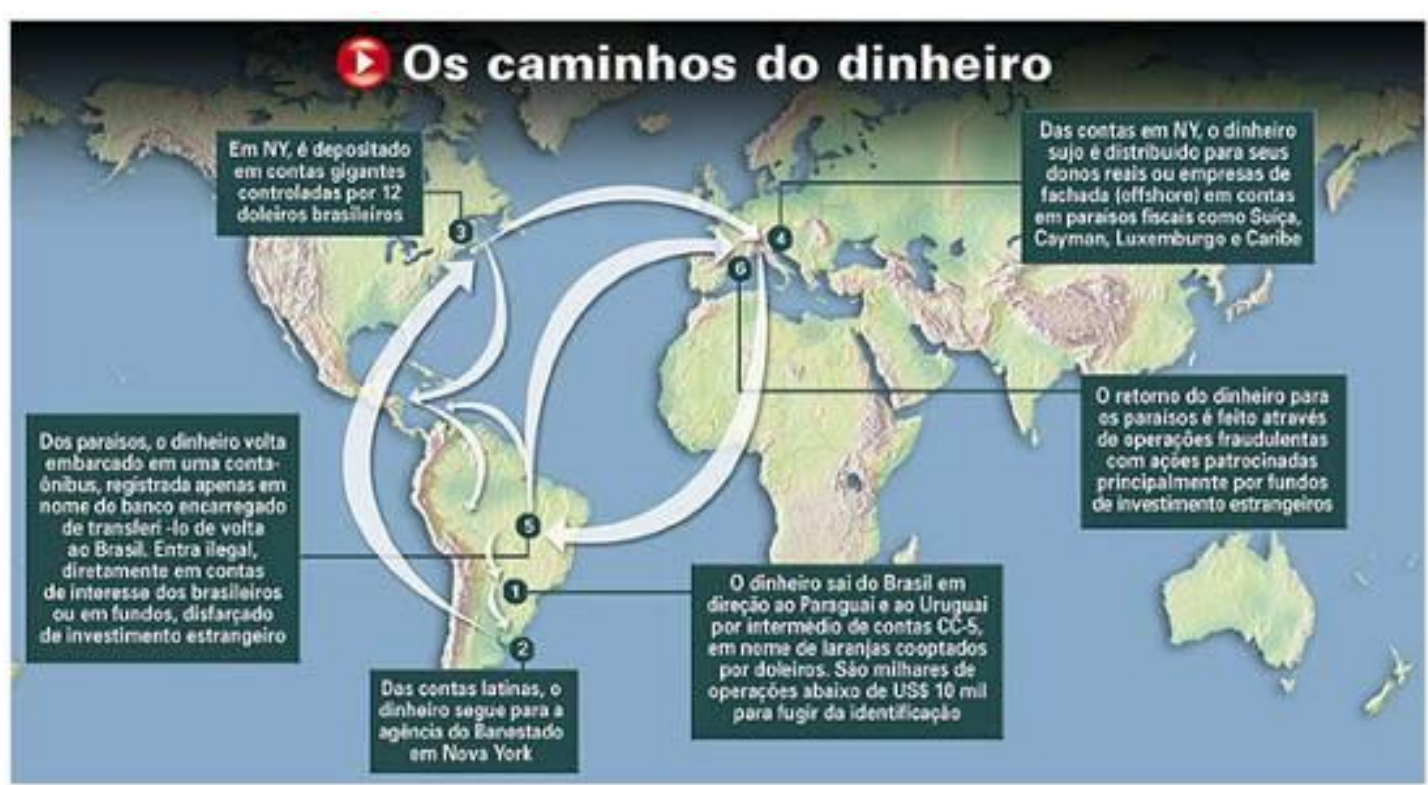

Figura 1: Os caminhos do dinheiro

Fonte: Istoé online (2010)

A Revista Istoé traz, ainda, em reportagem veiculada no ano de 2003, um relatório da Polícia Federal que aponta políticos, contrabandistas e traficantes que tiraram do Brasil cerca de US\$ 30 bilhões entre 2000 e 2003. O mesmo veículo de comunicação faz comparações entre como este absurdo valor que foi remetido para o exterior poderia ser investido em benefício do país: os R $\$ 30$ bilhões daria para sustentar o Programa Fome Zero (Programa criado durante o Governo Lula, que seleciona pessoas para receber assistência alimentar proporcionada pelo Estado) por 21 anos; bem como daria para cobrir os gastos da Previdência Social por 2 anos.

\section{PIRATARIA}

No que se refere à pirataria, tem-se neste crime um grande desafio, visto que já foi considerado, por muitos estudiosos, como o delito do século, de acordo com o Conselho Nacional de Combate à Pirataria e Delitos contra a Propriedade Intelectual (CNCP). O conceito de pirataria que consta no sítio "Pirataria: Tô Fora!" é o de que se trata de violações de direito de criação e autoria, em que a grande maioria de produtos pirateados é financiada por grupos de máfias internacionais.

No ordenamento jurídico brasileiro, o crime de pirataria e suas penalidades são previstos no artigo 184 do Código Penal e em vários outros dispositivos normativos, dentre o quais se destacam: a Lei 9.279/96 (Lei da Propriedade Industrial); Decreto 6.759/09 (Regulamento Aduaneiro); Decreto 1.355/94 (Propriedade Intelectual); e o Decreto-Lei $37 / 66$.

O artigo 184 do Código Penal Brasileiro traz a penalidade prevista para os crimes de pirataria, ao instituir a detenção de 3 meses a 1 ano, ou multa, para aqueles que violarem os direitos autorais, reproduzindo total ou parcialmente a obra intelectual. Já a Lei 9.279/96 (Lei da Propriedade Industrial) e o Decreto 6.759/09 (Regulamento Aduaneiro) trazem as circunstâncias em que os produtos pirateados, com marcas falsificadas, alteradas ou 
imitadas, podem ser apreendidos pelas autoridades alfandegárias. Esta apreensão deve ocorrer no ato da conferência, que pode ser de ofício ou a requerimento do interessado.

O Decreto 1.355/94 foi instituído após um tratado internacional que ocorreu no momento da Criação da Organização Mundial de Comércio. Este tratado é conhecido como Trade Related Aspects of Intellectual Property Rights (TRIPS) ou nacionalmente reconhecido como Acordo Relativo aos Aspectos do Direito da Propriedade Intelectual Relacionados com o Comércio (ADPIC). O artigo 59 deste decreto traz que as autoridades competentes, ocorrendo sem prejuízo dos demais direitos de ação do titular do direito e do réu, terão o poder de determinar a destruição ou a alienação de bens que violem direitos de propriedade intelectual.

Com relação ao Decreto-Lei 37/66, apresenta-se em seu artigo 105 a aplicação da pena de perda da mercadoria estrangeira que apresente característica essencial falsificada ou adulterada, que impeça ou dificulte sua identificação, ainda que a falsificação ou adulteração não influencie no seu tratamento tributário ou cambial.

De acordo com o Relatório da CPI da Pirataria (2004), a pirataria deixou de se apresentar como um crime específico, em que as atitudes ilegais possam ser definidas claramente. A pirataria apresenta-se, neste exato momento, como um conjunto de ações criminosas que se relacionam entre si, formando um complexo sistema ilegal que prejudica a sociedade como um todo. Dentre os crimes referidos pelo Governo, constata-se: contrabando, descaminho, falsificação de produtos e sonegação fiscal.

Há também outro tipo de crime, chamado contrafação, que geralmente é associado ao crime da pirataria. A contrafação, que não é tipificada no ordenamento jurídico brasileiro, ao contrário daquele, diz respeito à cópia de um determinado produto a fim de imitá-lo em todos os aspectos, desejando confundir o consumidor que irá utilizar o produto. Segundo Pedroza (2010):

A contrafação tem a sua origem no latim, contrafacere, o que quer dizer reproduzir por imitação, reprodução fraudulenta ou falsificação de qualquer ato ou coisa. $O$ abuso não se restringe a mercadorias, existindo também a contrafação de marcas, ou seja, uso indevido de marca de indústria, de serviço ou de comércio, em violação ao direito de seu proprietário. Dessa forma, a simples imitação, gerando a confusão por si só, caracteriza a citada contrafação.

Assim, a contrafação surge como um novo enquadramento jurídico, diferentemente da pirataria, que trata de uma falsificação de um produto, a fim de imitá-lo e de ludibriar o consumidor.

Com relação a dados estatísticos, apresenta-se um Relatório Pesquisa IBOPE- Instituto Brasileiro de Opinião Pública e Estatística- (2010), feito a pedido da Câmara de Comércio dos Estados Unidos e da Associação Nacional pela Garantia dos Direitos Intelectuais (ANGARDI). Esta pesquisa trouxe que aproximadamente $\mathrm{dR} \$ 18,6$ bilhões em impostos não são arrecadados por ano no Brasil, devido ao comércio ilegal e, principalmente, à pirataria. Outro dado estatístico, este feito pelo MJ -Ministério da Justiça- (2009), mostra que, no ano de 2009, foi apreendido aproximadamente 316 toneladas de medicamentos falsificados, em ações conjuntas feitas pela Receita Federal, Polícia Federal e Anvisa. Neste caso, mostra-se a ocorrência de dois crimes concomitantes, o contrabando e a 
falsificação de medicamentos, que pela lei brasileira constitui em crime hediondo com pena que vai de quatro a doze anos de prisão.

É importante ressaltar que a pirataria, além de prejudicar direta ou indiretamente toda a sociedade brasileira, traz também grandes repercussões internacionais, como a possibilidade de retaliações e advertências por parte de outros países devido aos altos índices de pirataria. Isto se deve ao fato de que alguns países reduzem tarifas de importação com relação a produtos exportados pelo Brasil, a fim de ajudar no desenvolvimento do país, não aceitando, desta forma, o comércio ilegal gerado pela pirataria.

Como forma de preocupação por parte do governo brasileiro e de entidades internacionais com relação à Copa de 2014 a ser realizada no país, foi feito recentemente um acordo entre a FIFA (Fédération Internationale de Football Association) e o INPI (Instituto Nacional de Propriedade Industrial), para proteger os produtos e a marca da FIFA. Segundo o sítio do INPI (2010), este acordo visa prevenir ações piratas ao invés de somente penalizá-las.

\section{DUMPING}

Por fim, o último crime a ser tratado neste trabalho é o dumping, que consiste na exportação de uma mercadoria com o preço abaixo do existente no mercado do país a que se destina, fazendo com que as empresas do país importador sejam extremamente prejudicadas. Isto se deve a prática ilegal de um preço de uma mercadoria bem abaixo dos seus reais custos de produção, gerando uma concorrência desleal com as empresas do outro país. Essa prática ilegal é penalizada de acordo com lei $\mathrm{n}^{\circ}$ 9.019/1995, que dispõe generalizadamente sobre a aplicação dos direitos previstos no Acordo Antidumping e no Acordo de Subsídios e Direitos Compensatórios. No que diz respeito à legislação restrita somente ao dumping, destaca-se o Decreto $\mathrm{n}^{\circ}{ }^{\circ} 1.602 / 1995$, que regulamenta os procedimentos relativos à aplicação de medidas antidumping e o Circular SECEX N. ${ }^{\circ}$ 21/1996, que estabelece o roteiro para elaboração de petição relativa à investigação de prática de dumping.

Para se constituir dumping é necessário analisar a existência de três características. A primeira diz respeito ao valor normal do produto, o usualmente utilizado para comercializar, e obtido através das operações comumente realizadas e pelo qual é consumido no mercado interno do país exportador. A segunda diz respeito ao preço de exportação do produto, ou seja, ao valor originário do produto que deixa o país exportador. E a terceira consiste no prejuízo destacado no mercado do país importador, em o dumping cause prejuízo a indústria local do país importador e que, principalmente, possa ser provado com o nexo causal entre esta atividade e o prejuízo econômico. Para tanto, é necessário que os produtos em conflito sejam vendidos num mesmo período de tempo, que sejam da mesma espécie e que estejam dentro de um mesmo sistema econômico.

Desta forma, o dumping, quando ocorridas as características descritas anteriormente, consiste num crime jurídico, já que é previsto em lei, e econômico, por trazer prejuízos às empresas dos país importador do produto. Além de que, extravasando o âmbito interno do país prejudicado, implica necessariamente nas relações internacionais dos países, desestabilizando a conjuntura comercial harmoniosa e provocando vários conflitos entre eles. Quanto à ocorrência ou não do crime de dumping, Franco (2005) afirma que: 
No entanto, é necessário aferir que nem todo dumping pode ser alvo de uma regulamentação anti-dumping. Dumping só pode ser condenável na medida em que causa prejuízo a um concorrente estabelecido no território do país importador. A prática de dumping visaria, principalmente, a eliminação do concorrente, através de uma prática desleal que usa do baixo preço para tal.

No que diz respeito aos procedimentos de investigação de dumping, tem-se a lei $\mathrm{n}^{\mathrm{o}}$. 9.019/1995, que regulamenta a forma de cobrança dos direitos, além de determinar a competência para a apuração de dumping para a Secretaria de Comércio Exterior, o SECEX, órgão ligado ao Ministério do Desenvolvimento, Indústria e Comércio. O SECEX, por sua vez, delega a competência da Defesa Comercial do Brasil ao DECOM (Departamento de Defesa Comercial), que executa as tarefas ligadas a área de dumping, como a análise do fato, petições, proposição e condução da investigação antidumping, dentre outras.

Com relação aos procedimentos a serem adotados, tem-se que este se inicia com a investigação da prática de dumping através de uma petição, cujo autor pode ser a indústria nacional prejudicada ou em nome dela. É importante destacar que devem ser demonstrados todos os fatos que comprovem a prática de dumping e que liguem essa prática à ocorrência de danos a empresa. Posteriormente, passa-se a petição ao DECOM, que deferirá ou não a petição após análise.

Em seguida, o DECOM acompanhará o decurso do processo junto a OMC, realizando os procedimentos necessários para se chegar ao deferimento ou não do pedido feito na petição, cumprindo o que está estabelecido na legislação doméstica, bem como seguindo as regras impostas pela $\mathrm{OMC}$, acordados em tratados internacionais, e que foram plenamente aceitas e incorporadas na nossa legislação.

A título demonstrativo, segue abaixo um gráfico que traz os principais países afetados com as investigações de práticas comerciais ilegais, dentre elas o dumping.

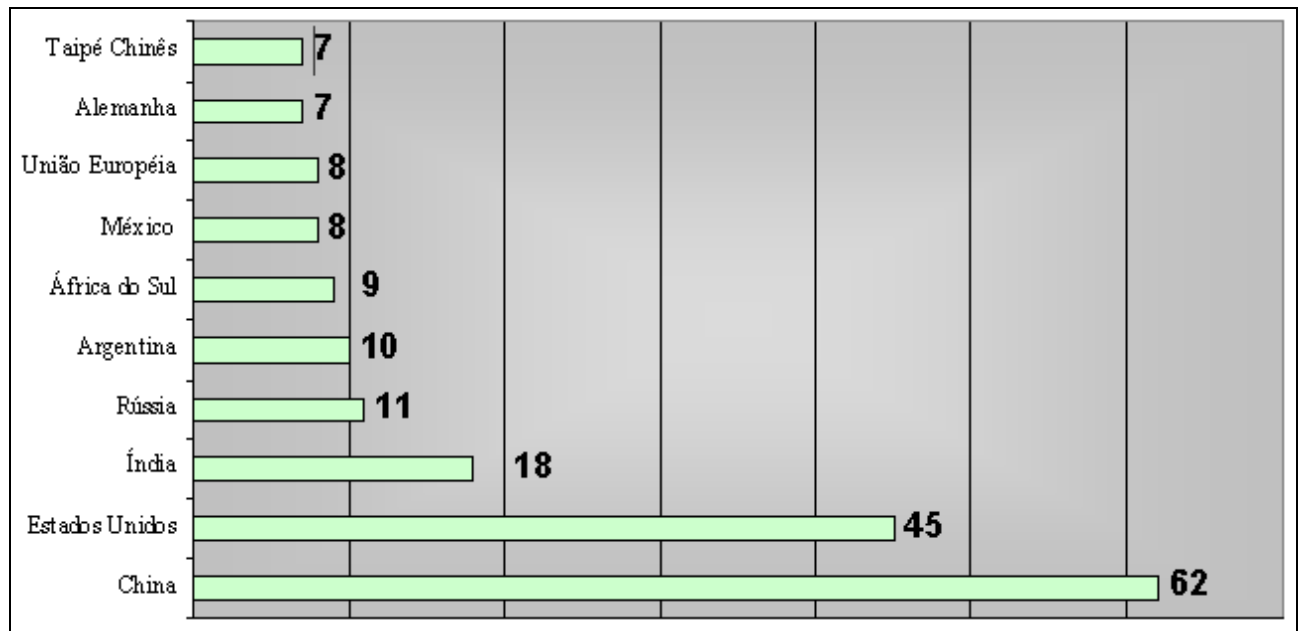

Gráfico 3: Investigações contra Práticas Desleais: Principais Países Afetados (1988-2008)

Fonte: DECOM (2008)

Observa-se que a China foi a que mais recebeu investigações contra práticas comerciais deslais, com $62 \%$ do total de investigações. Destaca-se, também, a indústria de produtos 
químicos, que registrou o maior número de investigações e penalidades impostas aos países pela OMC, seguido do setor de plásticos e o da siderurgia.

Quanto às investigações de prática de dumping ocorridas no Brasil, pode se observar outro gráfico abaixo obtido no sítio do DECOM.

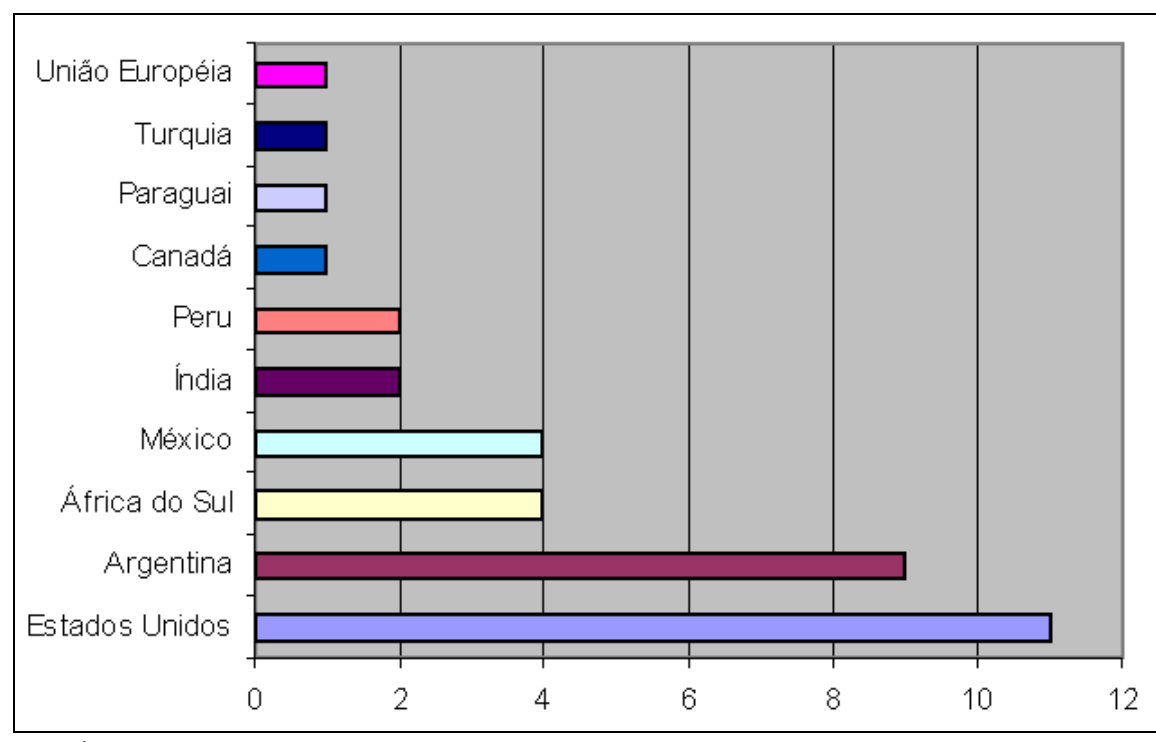

Gráfico 4: Investigações e medidas aplicadas contra exportações brasileiras

Fonte: DECOM (2007)

Neste outro gráfico é importante observar o número de pedidos feitos pela Argentina para investigar a existência da prática de dumping em determinados produtos brasileiros exportados. Isto se deve, em grande parte, à rivalidade histórica existente entre os países que tem o maior peso no MERCOSUL (Mercado Comum do Sul). Há de se observar também a liderança dos Estados Unidos no número de investigações solicitadas, resultado do grande número de comercializações do Brasil com este país, fazendo com que se aumente, proporcionalmente, a chance de incidência desta prática comercial desleal.

\section{ÓRGÃOS INTERVENIENTES E MEDIDAS FISCALIZADORAS CONTRA OS CRIMES NO COMÉRCIO INTERNACIONAL}

Os crimes no comércio internacional necessitam de medidas fiscalizadoras e repressoras, a fim de reprimir a ocorrência desses crimes e de penalizar quem comete esses delitos. Dentre os principais órgãos de combate aos crimes no comércio internacional no Brasil destacam-se a Receita Federal, a Polícia Federal, além de outros organismos, como o Conselho Nacional de Combate à Pirataria e Delitos contra a Propriedade Intelectual (CNCP), e o Fórum Nacional contra a Pirataria e a Ilegalidade. No âmbito mundial, o principal organismo de combate aos crimes no comércio internacional é o International Criminal Police Organization (INTERPOL).

Os órgãos de combate aos crimes no comércio internacional têm a missão de promover articulações entre os setores privado e público, visto que não bastam somente ações repressoras por parte do Estado, já que é de suma importância também que toda a sociedade esteja envolvida no combate a criminalidade. A atuação desses órgãos deve estar 
pautada em valores solidificados, como os que prezam a Receita Federal, conforme consta no seu sítio, que são: respeito ao cidadão, integridade, legalidade e profissionalismo.

Quanto às medidas adotadas, é essencial que estas estejam pautadas em ordenamentos jurídicos, ou se tratarem de organismos internacionais, em acordos ou convenções que tratem do assunto, e que sejam adotadas pelos países conflitantes. Isto resolveria possíveis questões de legalidade das medidas adotas pelos órgãos repressores, dando, assim, a competência e a segurança jurídica necessárias para o combate aos crimes no comércio internacional.

Após essas considerações iniciais, passa-se ao detalhamento de alguns organismos nacionais e internacionais que trabalham direta e indiretamente no combate aos crimes no comércio internacional.

A Receita Federal constitui no órgão nacional que mais atua na prevenção e punição dos crimes que envolvem o comércio internacional. Esta entidade atua diretamente no combate aos crimes de contrabando e descaminho, de acordo com o Programa Nacional de Combate ao Contrabando e ao Descaminho, instituído pelo Decreto $\mathrm{n}^{\mathbf{0}} 2.781 / 1998$. Além desta função, já citada anteriormente, destacamos o papel da Receita Federal, especificamente dos seus funcionários, os auditores fiscais, em reprimir o crime da lavagem de dinheiro, a pirataria, a evasão de divisas e a sonegação de impostos.

De acordo com o informe publicitário feito pelo UNAFISCO Sindical -Sindicato Nacional dos Auditores Fiscais da Receita Federal do Brasil (2010), as apreensões de mercadorias realizadas pela Receita Federal encontram-se em crescimento, apesar da deficiência de equipamentos específicos utilizados na vistoria e no confisco de mercadoria. Isto pode ser constatado com o gráfico abaixo:

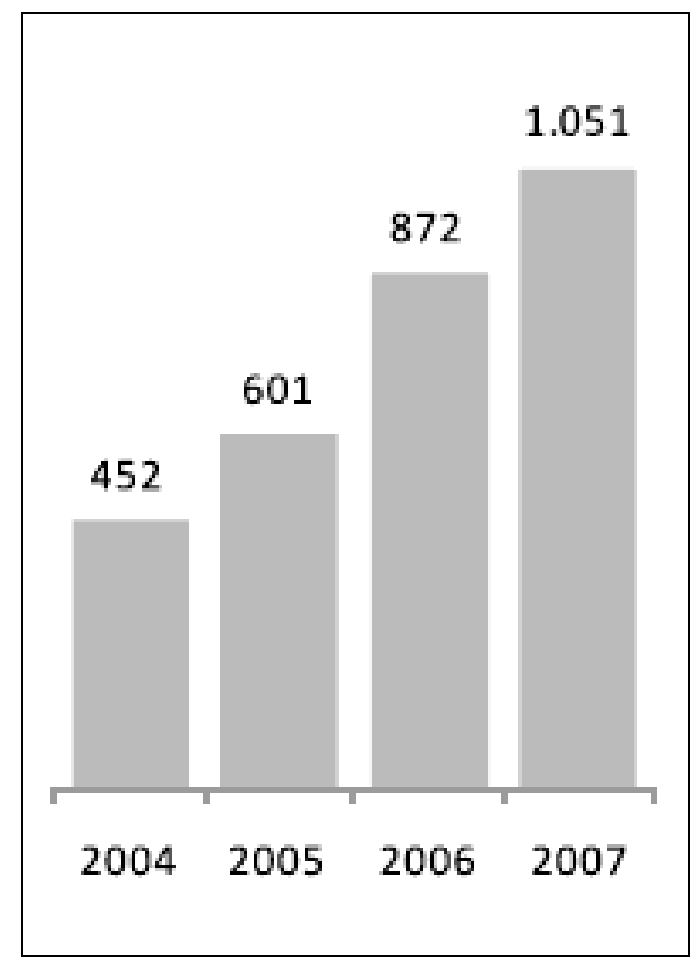

Gráfico 5 - Apreensões de mercadorias Fonte: UNAFISCO (2010) 
Para aperfeiçoar os seus trabalhos frente à repressão e punição dos crimes já listados, a Receita Federal, criou setores sob a sua supervisão, que se subdividem em coordenações, em que cada coordenação fica responsável pelo combate de determinado crime. Desta forma, criou-se a Coordenação Especial de Vigilância e Repressão (COREP), que se subdivide em vários setores chamados de Divisões de Repressão nas Superintendências (DIREPS).

A Receita Federal também investe maciçamente nas campanhas de conscientização da população como o Programa Nacional de Educação Fiscal (PNEF), que além de informar as pessoas quanto à questão fiscal como um todo, também aborda os assuntos pertinentes aos crimes no comércio internacional, como o contrabando, descaminho e evasão de divisas.

Quanto ao combate ao crime de evasão de divisas, a Receita Federal atua de forma concisa, agindo com o auxílio de outros órgãos, como a Polícia Federal e o Ministério Público Federal. Há de se destacar como principal área de combate a este crime, o setor de Inteligência Fiscal, que realiza trabalhos com foco na repressão ao crime de evasão de divisas, além de desarticular outros crimes antecedentes a este.

Desta forma, destaca-se o fundamental papel da Receita federal no combate aos crimes no Brasil, provenientes das transações e comercializações internacionais. Quanto a isto, devese reafirmar que a Receita Federal necessita de uma atuação conjunta com outros organismos, como a Polícia Federal, o próprio Estado e órgãos internacionais, para, juntos, combaterem os crimes no comércio internacional.

Outro importante organismo que atua na fiscalização e repressão dos crimes no comércio internacional é a Polícia Federal, órgão responsável pela investigação de crimes a nível nacional, especialmente os referentes ao contrabando, descaminho, tráfico de drogas e de armas, além dos crimes que atentem contra o sistema financeiro. Este organismo atua também nas fronteiras nacionais, exercendo a função de polícia marítima e aeroportuária. De acordo com o artigo 144 da Constituição Federal, a função da Polícia Federal é a de preservar a segurança das pessoas e do patrimônio nacional, sendo de sua responsabilidade prevenir e reprimir o tráfico ilícito de entorpecentes e drogas afins, o contrabando e o descaminho, sem causar prejuízo à ação fazendária e a outros órgãos públicos nas respectivas áreas de competência; e apurar infrações penais contra a ordem política e social e de outras infrações cuja prática tenha repercussão interestadual ou internacional e exija repressão uniforme.

Com relação ao Instituto Brasileiro de Ética Concorrencial ${ }^{6}$ (2010), constata-se que se trata de uma organização civil de interesse público, que abrange empresas nacionais e entidades não governamentais, com o intuito de promover um melhor andamento das negociações no comércio. Para isto, combate a evasão fiscal, falsificação e informalidade, já que considera estes crimes como sendo práticas sociais não éticas e que desequilibram a concorrência entre os produtos lançados no mercado. A sua área de atuação consiste em três esferas: conscientização, legislação e prevenção. No que tange à conscientização, destaca-se a meta desta organização em conscientizar a opinião pública acerca dos prejuízos causados por esses crimes, como a sonegação fiscal. Na área da legislação, a ETCO objetiva alcançar

\footnotetext{
${ }^{6}$ Instituto de Ética Concorrencial (ETCO).
} 
melhorias institucionais que estimulem a concorrência legal. Já no âmbito da prevenção, há o intuito em colaborar com as autoridades do Governo, contribuindo na melhoria dos instrumentos utilizados para se alcançar este fim.

No que se refere ao $\operatorname{DECOM}^{7}$ (2010), tem-se que este é um departamento que se insere na estrutura da Secretaria de Comércio Exterior (SECEX), que por sua vez está inserida no âmbito do Ministério do Desenvolvimento, Indústria e Comércio Exterior (MDIC). Este departamento é a autoridade brasileira responsável pelas investigações em casos em que há o direito de se aplicar medidas de defesa comercial do país. A questão da defesa comercial ocorre quando se analisa medidas a serem aplicadas no caso de dumping, outras práticas desleais e salvaguardas.

O Instituto de Direito do Comércio Internacional e Desenvolvimento ${ }^{8}$ (2010) consiste numa associação civil sem fins lucrativos e tem como principal ação o investimento em pesquisas e formação de pessoas, para que se alcance, cada vez mais, um sistema de comércio mundial mais junto e igualitário. Para isso, esta organização busca inserir o Brasil no cenário internacional, ao passo que trabalha junto a outros organismos para combater situações que ponham em risco as atividades comerciais do país. Assim, busca proteger os interesses nacionais, públicos ou privados, a fim de auxiliar de forma relevante no desenvolvimento de habilidades jurídicas para efetivar a justa participação do Brasil no cenário internacional. Quanto aos crimes no comércio internacional, nota-se a participação desta associação na formulação e divulgação de livros, e outros materiais de apoio, que combatam a prática desses crimes e que demonstrem claramente no âmbito jurídico, a infração a que estes crimes cometem, de acordo com a nossa legislação.

O Fórum Nacional Contra a Pirataria e a Ilegalidade ${ }^{9}$ (2010) é uma sociedade civil formada com o intuito de contribuir para o combate dos crimes no comércio internacional, dentre eles a pirataria, sonegação fiscal, contrabando, descaminho e o subfaturamento. Existe uma gama enorme de pessoas associadas a esta organização, representando boa parte de todos os setores comerciais no país, como o de livros, software, audiovisual, peças automotoras, fármacos e brinquedos. O FNCP age junto às instituições púbicas e privadas, promovendo a informação perante toda a sociedade, alertando-a quanto aos riscos e prejuízos que sofre ao consumir estes produtos ilegais. Assim, dispõe de um link de denúncias contra essas práticas ilegais e de um sistema no próprio sítio, que traz informações para a população em geral, bem como para os próprios agentes que atuarão diretamente no combate - fiscais aduaneiros, policiais federais -, para que possam consultar e atuar de uma forma mais eficaz. Há de se destacar que, recentemente, o FNCP colaborou de maneira decisiva para a formação da Comissão Especial de Combate à Pirataria (CEPIRATA), que foi criada pela Câmara dos Deputados com o objetivo de debater acerca dos problemas e das ações a serem adotadas com relação à pirataria e a proteção da propriedade intelectual.

O Conselho Nacional de Combate à Pirataria e Delitos contra a Propriedade Intelectual ${ }^{10}$ (2007) foi criado a partir de uma indicação feita no relatório da CPI da Pirataria, que mostrou a necessidade de que fosse criado um órgão púbico, com a colaboração de pessoas do setor privado, para que se combatesse de forma mais efetiva os crimes comerciais

\footnotetext{
${ }^{7}$ Departamento de Defesa Comercial (DECOM).

${ }^{8}$ Instituto de Direito do Comércio Internacional e Desenvolvimento (IDCID).

${ }^{9}$ Fórum Nacional Contra a Pirataria e a Ilegalidade (FNCP).

${ }^{10}$ Conselho Nacional de Combate à Pirataria e Delitos contra a Propriedade Intelectual (CNCP).
} 
transnacionais, dentre eles a pirataria, que alimenta inúmeras organizações criminosas. Assim, esta organização tem como missão propor e coordenar ações públicas e privadas para prevenir, por meio de medidas educativas e econômicas, e combater, por meio de medidas repressivas, o crime da pirataria, bem como os outros crimes correlatos, como o da sonegação fiscal, evasão de divisas e lavagem de dinheiro. Como plano de metas feito no ano de 2008 e que deve perpetuar até o ano de 2012, apresenta-se, resumidamente, os objetivos a serem alcançados na figura abaixo, que perpassam pelo âmbito da Governança, pelos processos internos e pelos resultados institucionais:

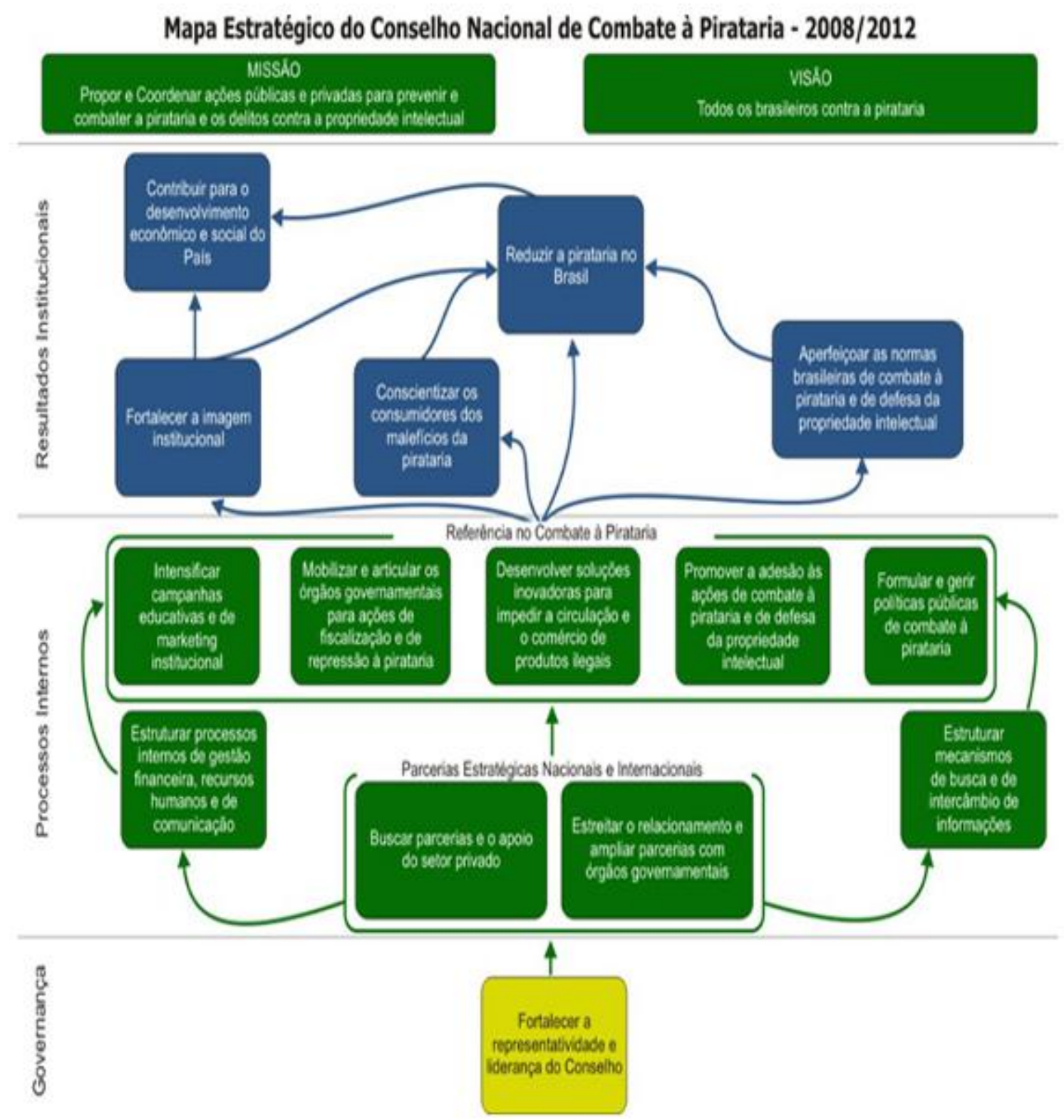

Ilustração 2: Mapa estratégico do Conselho Nacional de Combate à Pirataria 2008/2012

Fonte: CNCP (2007) 
A Agência Nacional de Vigilância Sanitária ${ }^{11}$ (2010) e o Instituto Nacional de Metrologia, Normalização e Qualidade Industrial ${ }^{12}$ (2010) constituem em organismos fiscalizadores de mercadorias que entram e saem do país, concedendo ou não a licença necessária para que ocorra efetivamente a comercialização desses produtos. Esta licença só será concedida, se o produto estiver dentro da conformidade estabelecida e prevista na legislação nacional. Para tanto, buscam informar e proteger o consumidor, particularmente quanto a sua segurança e saúde; estimular a melhoria e qualidade do produto a ser analisado; facilitar o comércio internacional e propiciar uma concorrência mais justa. Assim, a avaliação de conformidade feita por esses órgãos propicia um adequado grau de confiança de um produto, processo ou serviço, a fim de que este atenda aos requisitos estabelecidos em normas e regulamentos técnicos. No que diz respeito aos produtos oriundos do comércio ilícito, observa-se a grande atuação dessas entidades em fiscalizar os produtos oriundos do descaminho e contrabando, por exemplo, constatando na maior parte das vezes, os prejuízos causados por esses produtos devido a sua baixa qualidade.

Quanto aos organismos internacionais que se destacam no combate aos crimes no comércio que envolve o mundo inteiro, ressalta-se a International Criminal Police Organization ${ }^{13}$ (2010) e o International Chamber of Commerce ${ }^{14}$ (2010). A INTERPOL é uma agência internacional de polícia, que auxilia na aplicação das leis e tratados internacionais e ajuda na localização de criminosos que atuam em diferentes países. Os trabalhos realizados por esse organismo, como os protocolos, a formação de bases de dados da organização e os alertas internacionais, são essenciais para o combate aos crimes comerciais internacionais. Já o ICC contribui de forma essencial pra o combate aos crimes no comércio internacional à medida que expõe, ao mundo empresarial, as questões-chaves que envolvem o comércio, dentre elas o quesito da propriedade intelectual frente ao cenário internacional. Este organismo internacional atua também na modernização aduaneira, bem como investe na implementação da transparência, simplificação e harmonização de políticas e procedimentos aduaneiros, debatendo este assunto mundialmente.

\section{MPACTOS LIMITANTES E FACILITADORES NO QUE TANGE O COMBATE AO CRIME NO COMÉRCIO INTERNACIONAL}

Os crimes no comércio internacional são constituídos por práticas comerciais ilícitas que muitas vezes são impulsionadas por elementos facilitadores para a sua ocorrência. Desta forma, existem vários fatores intervenientes que contribuem para a consecução dos crimes no cenário internacional, visto que funcionam como agentes que tendem a aumentar a chance de ocorrência destes crimes. O Brasil possui aproximadamente 16,8 mil km de fronteira terrestre, de acordo com o Relatório Anual de Atividades do Departamento de Polícia Federal (2008), em que existem regiões não habitadas e de difícil acesso, o que facilita a entrada dos produtos ilegais em seu território. Abaixo, apresenta-se uma figura que ilustra a extensão das fronteiras do Brasil:

\footnotetext{
11 Agência Nacional de Vigilância Sanitária (ANVISA).

12 Instituto Nacional de Metrologia, Normalização e Qualidade Industrial (INMETRO).

${ }^{13}$ International Criminal Police Organization (INTERPOL).

${ }^{14}$ International Chamber of Commerce (ICC).
} 


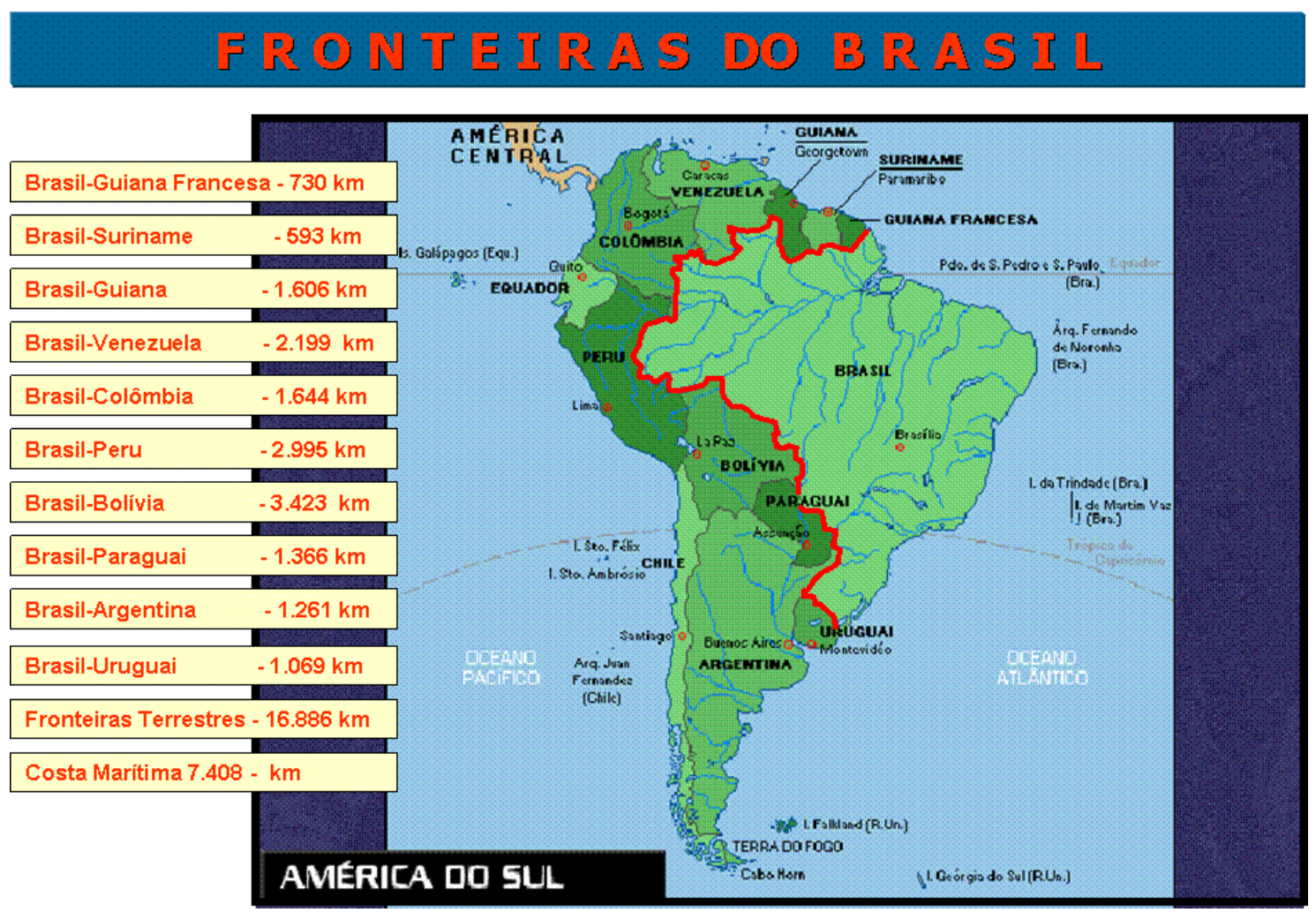

\section{Mapa: Fronteiras do Brasil Fonte: DPF (2008)}

Neste sentido, os limites dos países deverão ser previstos juridicamente e controlados, como afirma Salvo (2010), em seu artigo, ao dizer que:

No âmbito do sistema de estados nacionais, os limites devem atuar como filtros aos fluxos internacionais. Neste sentido, podem ser mais ou menos permeáveis, podendo inclusive ser dissolvidos no que diz respeito a certos intercâmbios, em função dos sistemas jurídicos internos que regulam as políticas aduaneiras, migratórias, sanitárias, etc.

Assim, no que concerne o sistema estrutural dos principais órgãos fiscalizadores, observase que falta ainda uma estrutura solidificada, especialmente no que diz respeito à Aduana brasileira, que é responsável por fiscalizar e autorizar a entrada e saída de produtos do território nacional. Para isto, a Aduana fornece documento específico para a comercialização, como é o caso da Declaração de Importação, para posteriormente permitir ou não a passagem deste produto.

A Aduana, por ser o órgão da Receita Federal, que é o organismo que mais combate a prática de crimes no comércio internacional no país, passa por sérias dificuldades, necessitando de reformas urgentes para se mudar este quadro, fortalecendo cada vez mais esse organismo.

No que diz respeito a este assunto, destaca-se que o trabalho de alguns auditores fiscais na Aduana é prejudicado devido ao grande número de cargas a serem vistoriadas ser inversamente proporcional ao número de servidores da Receita Federal disponíveis para este trabalho. Os auditores reclamam que estão trabalhando sobrecarregados com um trabalho extremamente burocratizado. 
Quanto a isto, Lemos (2008) preleciona a criação de novos cargos da Aduana, a fim de ajudar nas atividades dos auditores fiscais para dinamizar o trabalho bastante burocratizado. Uma das propostas defendidas pelo mesmo autor é o da criação do cargo de servidores de nível médio para trabalhar em áreas de menor complexidade. Esses servidores ficariam sob a supervisão dos auditores fiscais, sendo treinados por eles.

O que se pretende alcançar com essa proposta é o trabalho mais eficaz na Aduana, sem o dispendimento de recursos humanos, que com uma melhor divisão de tarefas, poderiam ser melhor alocados, gerando benefícios para todo o sistema. Assim, a fiscalização, essencialmente na Zona Primária, seria mais eficaz, evitando a entrada de produtos contrabandeados e coibindo o descaminho.

Assim, não se pretende o dispêndio de mais tempo utilizado para a verificação, já que sabemos que o comércio exterior está cada vez mais ágil e que precisamos de um sistema ágil e eficaz capaz de não comprometer o desenvolvimento do país. É notória a importância dos superávits da balança comercial para o crescimento econômico do país, mas não se pode esquecer também da importância de se preservar a indústria nacional, e principalmente, a saúde e bem-estar da população brasileira.

Segundo Lemos (2008):

Uma atuação mais ostensiva na zona primária com o apoio de um corpo funcional auxiliar poderia reduzir a grande quantidade de produtos contrabandeados que se utiliza dessa fragilidade para entrar no país. O reaparelhamento da aduana possibilitaria não só retornar aos seus verdadeiros objetivos de proteção e segurança do país, como poderia contribuir para a redução da pirataria, ampliando a proteção do comércio e da indústria.

Nesta mesma linha de raciocínio, Franca (2008) afirma que embora as fronteiras brasileiras sejam extremamente grandes, ainda é mais viável fazer a fiscalização nas Zonas Primárias nesses pontos, do que realizar operações de apreensão de mercadorias dentro do território brasileiro, que é muito mais vasto.

Outro fator que dificulta a atuação da Receita Federal é o grande esquema armado para fomentar as práticas ilícitas, como o contrabando e descaminho. Quanto a isto, Franca (2008) diz que:

\begin{abstract}
Deve-se levar em conta, também, que a quantidade de pessoas envolvidas com o contrabando é enorme, o que lhes possibilita praticar ininterruptamente essa atividade, usando batedores móveis e a 'estrutura de postos e restaurantes nas estradas para avisar os transportadores sobre possível atuação da repressão, em qualquer dia e horário e nas piores condições climáticas, ao passo que a SRF ainda não está estruturada em termos de pessoal e mesmo de logística para reprimir os ilícitos de forma permanente.
\end{abstract}

Outra questão que deve ser analisada é dos equipamentos disponíveis para serem utilizados pela Receita Federal para prover de forma satisfatória e necessária a fiscalização das mercadorias que entram e saem do país, pelos portos, aeroportos e pelas vias terrestres. No que diz respeito a este assunto, constata-se que o arsenal disponível para a realização dessas atividades fiscalizadoras é baixíssimo, embora haja constantes investimentos nesta área. De acordo com Franca (2008), os principais portos nacionais, como Santos, Vitória, Paranaguá e Rio de Janeiro, adquiriram recentemente lanchas, dois helicópteros e 
aparelhos de raios-X para inspecionar cargas, mas em número considerado aquém daquele que realmente eles necessitariam ter. Lemos (2008) ainda traz, a título comparativo, que a Aduana dos Estados Unidos dispõe de mais de 250 aeronaves e 200 embarcações para utilizar nas fiscalizações das suas fronteiras.

Há ainda também outro fator que dificulta a atuação dos profissionais da Receita Federal, que é o de discriminação destes por parte da população de algumas regiões, que se vêem prejudicados com a atuação da Receita Federal. Isto se deve a aceitação popular dos crimes que envolvem o comércio exterior, como o contrabando, descaminho e pirataria, impulsionada pelos baixos preços que esses produtos são vendidos em território nacional. Esta informação é discutida internamente nas Secretarias da Receita Federal, e segundo Franca (2008), ocorre principalmente nos casos em que há apreensão de mercadorias de pessoas mais desfavorecidas, que tentam intimidar a autoridade fazendária ao argumentar que estão tirando dela o seu meio de subsistência, e tratando os auditores fiscais como profissionais "truculentos, violentos, cruéis ou agindo com excesso ou abuso de autoridade".

Outro fator interveniente é a carga tributária excessiva incidente sobre o produto legalizado comercializado, já que estará embutido nele todos os impostos devidos. Assim, com essa alta carga tributária, as empresas estão cada vez mais oneradas e, de acordo com Medeiros (2005, p. 31):

\footnotetext{
Cria um círculo vicioso. As pessoas passam a consumir os bens mais baratos, em detrimento daqueles legalmente produzidos e mais caros, devido ao fato do fabricante ter pago o imposto sobre produtos industrializados - IPI, Imposto sobre Circulação de Mercadorias- ICMS, PIS/COFINS, e sei lá mais quantos. Consequentemente o governo perde receita e, de novo, aumenta o imposto. Os consumidores continuam a procurar os bens mais baratos, o contrabando cresce, o governo perde receita e isso não pára...
}

A população que consome os produtos falsificados ou provenientes do mercado ilícito alega que a forma que ela tem para ter acesso à cultura e aos bens de consumo é comprando neste mercado ilegal. Assim, os consumidores justificam essa prática afirmando que o preço dos produtos "originais" e de origem lícita está muito caro e que não tem capital suficiente para comprar esses produtos.

Num estudo realizado pela Federação do Comércio do Estado do Rio de Janeiro FECOMÉRCIO-RJ (2007), constatou-se que quase metade dos brasileiros compraram produtos falsificados no ano de 2009. O que mais alarma é que uma boa parcela dos entrevistados sabe dos efeitos negativos causados por esse comércio ilegal: cerca de $60 \%$ afirmaram saber que estes crimes causam desemprego e aproximadamente $69 \%$ disseram que sabiam que estas práticas financiavam o crime. Isto aponta que no que diz respeito à conscientização, uma parte da população já está a par dos efeitos, mas que ainda devem ser feitas campanhas conscientizadoras para atingir o máximo de pessoas possível, e informálas que existem muitos outros efeitos gerados pelos crimes no comércio internacional que afetam diretamente a vida dessas pessoas.

Assim, como exemplo do que está sendo discutido aqui, demonstra-se o caso do preço do $\mathrm{CD}$ original que é composto por gasto com a fabricação, lucro a ser auferido, imposto, custos com distribuição, marketing, gravação, produção, royalties e copyright, enquanto que na pirataria, gasta-se apenas com a fabricação do CD. (NERI, 2005) 
A título ilustrativo, tem-se o gráfico abaixo que mostra o que foi exposto no parágrafo anterior:

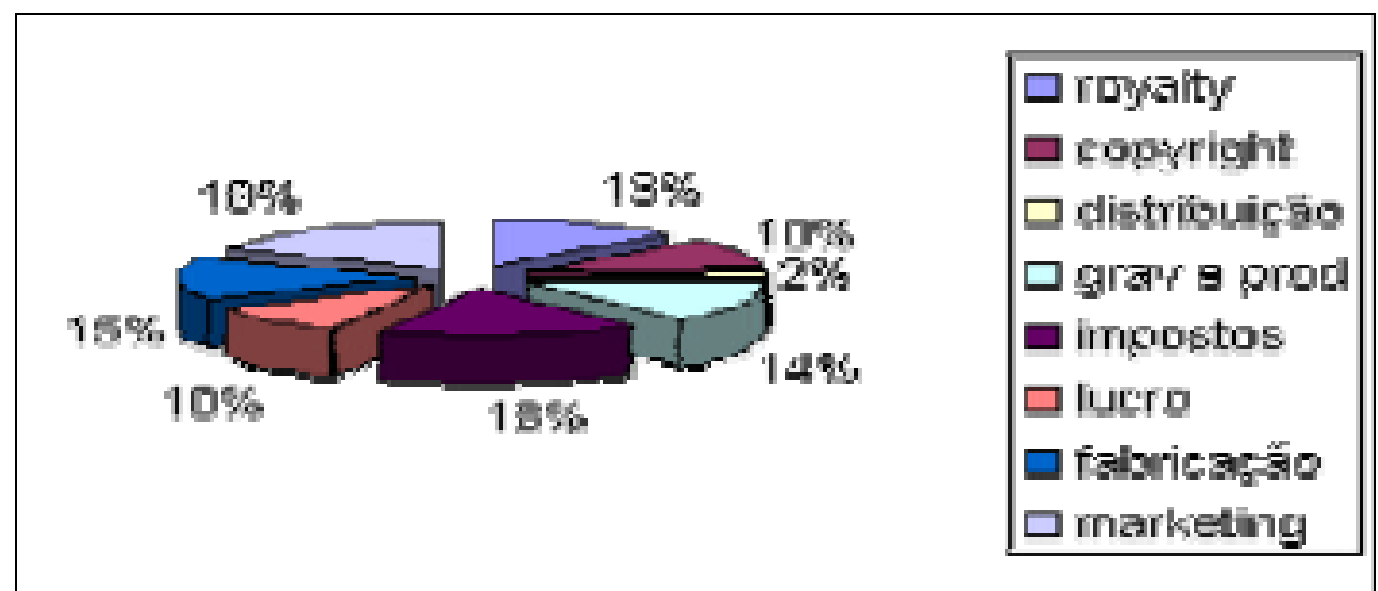

\section{Gráfico 6 - Custo Médio do CD \\ Fonte: ABPD (2006)}

Desta forma, é evidente que a concorrência existente entre um CD original, que foi usado com exemplo, e outro falsificado é completamente desleal, impulsionando a população que tem menor renda a comprarem os produtos piratas. É importante destacar que a pirataria desse setor advém de CDs virgens contrabandeados, geralmente oriundos do sudeste asiático, que remetem para grupos de brasileiros que cometem essa prática ou para países vizinhos, como o Paraguai, que grava cerca de $30 \%$ dos CDs que recebem com música brasileira, e por fim remetem ao Brasil. (CPI da Pirataria - Relatório)

Há de se destacar também a alta carga tributária geral no país, que passou de $24 \%$ no ano de 1991 para aproximadamente $35 \%$ no ano de 2004, de acordo com o Relatório da CPI da Pirataria (2004). Esta alta carga tributária incide basicamente sobre a produção e o consumo no país, onerando de forma incisiva o empresário que tenta prosperar o seu negócio. Em outros países, a carga tributária chega até a ser maior do que a incidente no Brasil, mas nesses locais o tributo é cobrado principalmente sobre a renda e a propriedade, além de que os serviços prestados pelo Governo são de boa qualidade e suprem a necessidade da população.

Assim, o preço final do produto legalizado se torna mais caro devido aos gastos que os empresários têm com o pagamento de tributos, como o ICMS e o IPI, tendo que repassar esses custos para o consumidor. O consumidor, por sua vez, não se vê em condições de comprar aquele produto legalizado, e procura outras alternativas para suprir a sua necessidade e desejo de ter aquele produto, buscando o produto de origem ilegal.

Outro fator interveniente e que contribui para o aumento da incidência dos crimes no comércio internacional é a aceitação social de condutas consideradas eticamente irrelevantes em comparação aos benefícios proporcionados e aos impactos gerados. Assim, de acordo com Salvo (2010):

Isso significa reconhecer que os indivíduos não decidem apenas motivados por circunstâncias econômicas ou sociais, mas também influenciados por valores culturais e morais aprendidos na convivência social; as pressões oriundas do ambiente externo sofrem a mediação da consciência e dos seus valores morais. 
Desta forma, a população utiliza da justificativa de não ter a renda necessária para poder comprar produtos oriundos do mercado lícito, devido aos altos índices de desemprego existentes no país, a pobreza que atinge a maior parte da sociedade brasileira e que incentivam o consumo destes produtos. Por outro lado, destacam-se os vendedores que utilizam da prerrogativa de não terem acesso ao mercado de trabalho para se inserirem neste mercado ilegal, como forma de sobreviver frente às adversidades do país.

Há também o lado dos grandes comerciantes que objetivam ganhar mais dinheiro nas suas transações através do meio ilícito, sonegando impostos, subfaturando importações ou exportações, e utilizando de outros meios ilegais para alcançar este fim. Estes comerciantes também acreditam que não trazem prejuízos consideráveis para a economia e indústria nacional, por acharem que se trata de um caso isolado que não irá influenciar nos níveis de emprego e renda do país.

Isto já está tão enraizado na sociedade brasileira, que usando da prerrogativa de que não está prejudicando ninguém, só está se procurando um meio de sobrevivência, que já atinge a esfera da ética da sociedade. Isto, muitas vezes é facilitado pelo próprio Governo, que faz vista grossa frente às evidências e mandam a responsabilidade de fiscalizar e reprimir para os órgãos públicos, dirimindo sua responsabilidade e repassando para outros setores, o que gera um ciclo sem fim.

Muitas vezes o Poder Executivo propicia de alguma forma a execução desses crimes no comércio internacional, como preleciona o Relatório da CPI da Pirataria (2004, p. 270):

\footnotetext{
No contexto das autoridades, algumas chegam a constituir camelódromos ou feiras de importados, arrecadam algum imposto, algum ICMS, alguma taxa de localização. De IPI, imposto de importação, nem pensar. Pensam estar provendo emprego e renda; de fato, estão, mas mediante atitudes ilegais que conduzem à informalidade e à marginalidade, que fazem fronteira com o crime. Se há uma proposição genérica que esta CPI demonstrou foi a de que essas inocentes atividades informais, em nível mais profundo, vinculam-se ao crime e, eventualmente, a organizações criminosas.
}

Isto demonstra o quanto se deve ainda avançar nesta questão, ao passo de que estes problemas aqui expostos dificultam o trabalho de punição e prevenção desses crimes, ao mesmo tempo em que facilita a ocorrência destes. Pode-se citar ainda, de maneira contundente, que os crimes no comércio internacional foram amplamente facilitados por valores crescentes trazidos pela globalização. Como exemplo deste fato, Mingst (2009, p. 122) afirma que as práticas ilícitas foram impulsionadas pelas múltiplas rotas de transporte, rápida comunicação e acesso a redes criminosas. Mingst traz também como agente facilitador neste caso, a burocracia rígida dos Estados, os procedimentos demorados e trabalhosos, além de ter o fato de funcionários corrompidos por essa máfia que minam os esforços dos Estados.

O autor Naím, ainda afirma que alguns Estados mantêm diversas práticas internacionais ilegais justamente por beneficiar a elite dominante desses países, que conseguem grandes lucros nessas atividades ilegais. Isto mostra mais uma vez a máquina estatal funcionando contra os interesses gerais da sociedade, a fim de beneficiar um grupo específico da população (NAÍM, 2006). 
Por fim, pode-se citar mais dois fatores intervenientes que facilitam as ações criminosas no comércio internacional, que são a escassez de políticas públicas e a falta de investimentos para informar a sociedade acerca dos seus efeitos produzidos. Estes dois fatores podem ser abordados conjuntamente, visto que advêm de um mesmo cerne, que é o da falta de investimento por parte do Poder Público para que se antecipe à ocorrência destes crimes e atue de forma incisiva na prevenção destes crimes, ou que atue na repressão dos mesmos de forma mais contundente.

De acordo com Naím (2006, p.227):

\begin{abstract}
Os governos, porém, precisam fazer parte da resposta. Da maior parte na verdade. A batalha contra o comércio ilícito clama pela criação e implementação de novas leis, prerrogativa exclusiva de governo. Exige a cooperação entre os órgãos de justiça, polícia e inteligência de vários países. Sem a autoridade legal e a força coercitiva dos governantes, a luta já estaria perdida.
\end{abstract}

Observa-se, assim, a necessidade de políticas públicas para combater os crimes no comércio internacional, com a adoção de medidas preventivas e repressivas em conjunto com outros países.

\title{
IMPACTOS SOCIOECONÔMICOS INCIDENTES NO BRASIL
}

A queda na arrecadação fiscal, ou até mesmo a não arrecadação de tributos, é o principal impacto socioeconômico gerado pelos crimes no comércio internacional. De acordo com Medeiros (2005), isto faz com que ocorra menos aplicabilidade de investimento na sociedade, como na educação e saúde, contribuindo para um déficit cada vez maior das contas públicas. Há de se destacar também outros danos causados pelos crimes no comércio internacional, especialmente o de evasão de divisas e o dumping, já que estes crimes prejudicam toda a sociedade ao influenciar a economia nacional, pois desviam irregularmente dinheiro do país e realizam práticas comerciais desleais, prejudicando a geração de empregos e o desenvolvimento das indústrias no país.

De acordo com o representante da Receita Federal no Rio Grande do Note, que concedeu depoimento que constitui num importante objeto de investigação deste trabalho, o dumping é considerado como prática comercial não aceita, visto que não existe uma penalidade num primeiro momento, sendo necessária a análise da situação para a posterior comprovação da infração. Somente após esta análise, é que se pode solicitar o ressarcimento de prejuízos causados à empresa nacional, almejando, assim, coibir novas práticas ilícitas e proteger também a indústria nacional.

Além do dano econômico causado pelos crimes no comércio internacional, há ainda danos mais perniciosos que ultrapassam este âmbito, já que atingem também a esfera da saúde e segurança das pessoas. Os consumidores que compram estes produtos, seja contrabandeados, que sofreram descaminho ou pirateados, são prejudicados ao passo que estas mercadorias não passaram por um controle para entrarem regularmente no país, podendo causar danos irreversíveis à saúde dessas pessoas.

Vismona (2010), presidente do Fórum Nacional contra a Pirataria e a Ilegalidade e do Instituto do Brasil Legal, em matéria veiculada no jornal "O Estado de São Paulo", 
exemplifica os prejuízos causados aos consumidores pelos produtos oriundos do mercado ilícito:

Tênis piratas causam problemas ortopédicos; brinquedos que soltam partes e que são feitos com material hospitalar podem matar uma criança; peças de automóveis sem atender as especificações de segurança causam acidentes; computadores ilegais, com programas igualmente ilegais, põem a perder o trabalho; óculos piratas afetam os olhos, pois enganam a retina com uma falsa proteção aos raios UV. Enfim, o esperto, pensando que está levando vantagem, está prejudicando a si mesmo.

Assim, constata-se outro impacto negativo, que são os prejuízos causados à saúde pública, em que boa parte dos produtos falsificados, pirateados e contrabandeados geram à sociedade, por não terem a fiscalização devida. Os impactos prejudiciais gerados à população podem ser constatados mais uma vez quando se trata de falsificação de medicamentos, em que não há qualquer tipo de controle na área da saúde, podendo causar até a morte das pessoas que consomem este produto, já que há um tratamento incorreto e a fórmula do medicamento de origem ilícita muitas vezes trata-se se uma substância ofensiva ao organismo. (MEDEIROS, 2005)

Sobre este assunto, o auditor fiscal constata que a não adequação do produto ao mercado nacional prejudica os consumidores finais daquela mercadoria, bem como toda a indústria nacional, afirmando que:

A questão dos controles (tratamentos administrativos das operações de comércio exterior - exportação e importação) tem como finalidade adequar os produtos que entram e saem à nossa realidade. Assim, a nossa economia tem um padrão de produção já estabelecido, fazendo com que muitas vezes ela não tenha condições de concorrer de forma direta com as mercadorias produzidas em outros países, que não atendem a esta regulamentação.

Nesta linha de raciocínio, pode-se exemplificar como um dos controles administrativos citados pelo representante da Recita Federal a fiscalização feita pelo INMETRO nas mercadorias que entram no país, de forma a adequar o produto à nossa legislação. Desta forma, as mercadorias que não sofrem este tipo de controle e que adentram no nosso mercado, irão competir deslealmente com os produtos nacionais, que em regra, cumprem todas as recomendações dadas pelos órgãos fiscalizadores, prejudicando assim mais uma vez, a indústria e economia nacional.

Medeiros (2005), ao discutir acerca dos danos causados pelos crimes no comércio internacional, traz dados relativos aos prejuízos causados pela pirataria, ao afirmar que este crime provoca a evasão de aproximadamente $\mathrm{R} \$ 10$ bilhões por ano, valor este que corresponde ao dinheiro que o Governo deveria gastar em educação, saneamento e habitação no ano de 2002.

Segundo dados mais recentes, publicados pela Câmara de Comércio Internacional, a pirataria movimenta cerca de $7 \%$ do comércio mundial, o que corresponde a aproximadamente US\$ 600 bilhões, o que supera facilmente os US\$ 360 bilhões provenientes do narcotráfico. E de acordo com o Instituto Brasileiro de Ética Concorrencial (ETCO), se juntarmos os crimes da pirataria, com o contrabando e os outros crimes que cercam o comércio ilegal, o valor movimentado pela economia informal chega 
a ultrapassar $\mathrm{R} \$ 850$ bilhões por ano, o que equivale a cerca de $30 \%$ do Produto Interno Bruto (PIB).

Estes dados mostram a grandiosidade de verba pública não arrecadada pelo Governo, gerando déficit na arrecadação fiscal, fato que, segundo o representante da Receita Federal no $\mathrm{RN}$, eleva a carga tributária do país, "pois quando nem todos pagam, alguns vão ter que pagar mais do que os outros".

Assim, o déficit gerado na arrecadação de tributos deve ser suprido para a manutenção dos compromissos do Estado, gerando, desta forma, outra implicação fiscal, que seria a elevação da carga tributária para se alcançar este objetivo. No entanto, sabe-se que o segmento da população que mais sofre com o aumento da carga tributária é o dos mais pobres. De acordo com o consultor de finanças públicas Amir Kahir, em entrevista concedida ao jornal Folha de Alphaville online, "quem paga imposto no Brasil é da classe média para baixo". Segundo este especialista, quem ganha até 2 salários mínimos paga até 49\% do que ganha em tributos, e responde pela maior parte da arrecadação tributária do país, e quem ganha acima de 30 salários mínimos paga apenas $26 \%$ dos seus rendimentos em tributo (COSTA, 2009). Este descompasso arrecadatório irá influenciar em vários outros ramos da sociedade, surtindo efeito, inclusive, no aumento da criminalidade nacional.

Trazendo mais uma vez os efeitos gerados para o âmbito nacional, apresenta-se, como preleciona Medeiros (2005), que cerca de 1,5 milhões de empregos não são gerados por causa da pirataria, e aproximadamente 7.200 empregos, somente na área de brinquedos não são criados devido a invasão de produtos chineses no mercado brasileiro, de acordo com a Associação Brasileira dos Fabricantes de Brinquedos (Abrinq). Isto mostra o impacto negativo causado na economia brasileira pela entrada de determinados produtos, que muitas vezes não possuem a autorização do Governo Brasileiro, implicando na não geração de empregos e na queda do desenvolvimento da indústria nacional.

Quanto a isto, tem-se a tabela 1 que mostra uma simulação de perdas da indústria nacional com a pirataria para as cidades de São Paulo, Belo Horizonte, Recife e Rio de Janeiro. Esta tabela 1 retrata as perdas da indústria de acordo com as diferenças de preços dos produtos, quando se apresenta uma variação com o produto original de $25 \%, 50 \%$ e $75 \%$.

Tabela 1: Impacto da pirataria na indústria

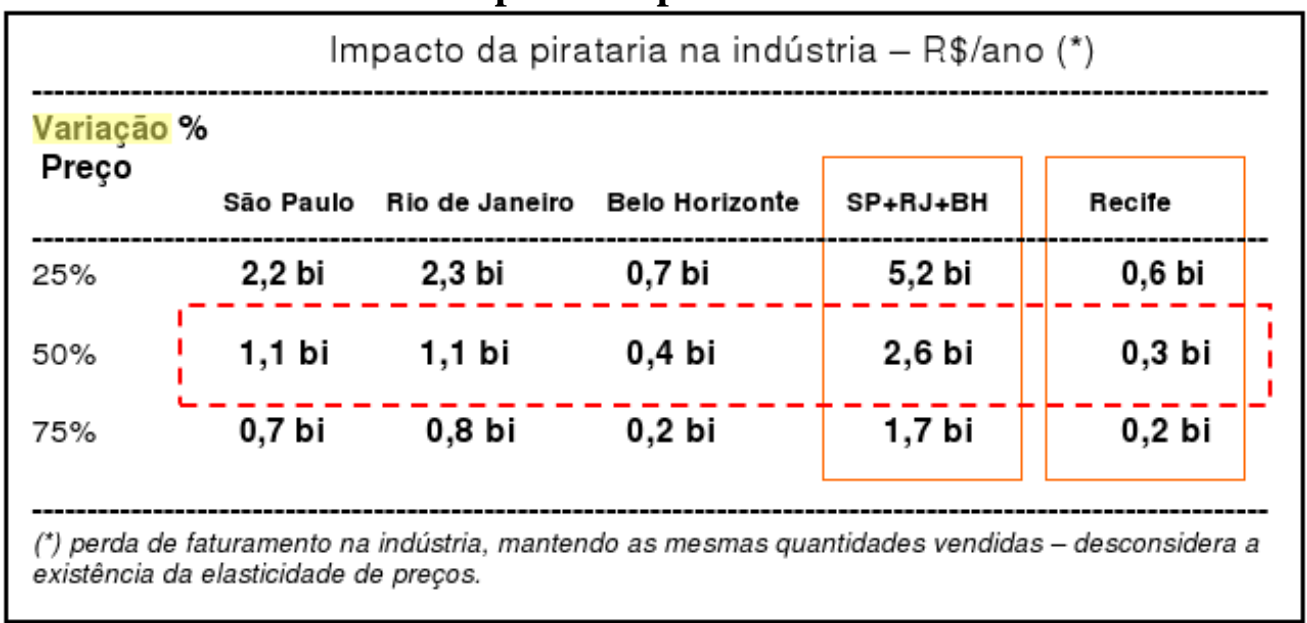

Fonte: Relatório Pesquisa IBOPE (2010) 
Outro efeito gerado pelos crimes no comércio internacional é o do financiamento da criminalidade no mundo inteiro, destacando-se o papel das máfias que são, em sua maior parte, sustentadas pelo capital proveniente dessas práticas ilícitas. Isto gera repercussões mundiais, ainda mais com a ameaça terrorista cada vez mais presente no cenário internacional, influenciando toda a comunidade e economia mundial. Assim, muitos países estão se fechando para o mercado ou estão impondo barreiras tarifárias e não-tarifárias a fim de fiscalizarem melhor as transações comerciais, dificultando o próprio comércio.

Quanto ao sistema organizacional destes núcleos criminosos, sabe-se que se trata de organizações bem estruturadas e muitas vezes solidificadas no cenário comercial mundial. Quanto a isto, Naím (2006, p. 11) discorre:

\begin{abstract}
Ao longo do século XX, à medida que os governos passaram a prestar atenção no comércio ilícito, consideraram-no uma atividade de organizações criminosas, e essa visão era compartilhada tanto pelos governantes quanto pela opinião pública. Conscientemente ou não, investigadores do mundo inteiro, tomaram como parâmetro as máfias americanas e siciliana, e, impulsionada por essa mentalidade, a caçada aos traficantes - quase sempre de drogas- levou a organizações que os investigadores julgavam ser próprias do sistema corporativo: estruturadas, disciplinadas e hierarquizadas.
\end{abstract}

Assim, os crimes no comércio internacional fomentam a criminalidade interna e transnacional, ao passo que os lucros gerados nesses crimes e os meios utilizados para o alcance destes, injetam grande quantidade de capital e financiam parte das ações criminosas. Concomitantemente, observa-se a ocorrência de vários crimes transnacionais no mesmo momento, como por exemplo, os crimes de evasão de divisas e da pirataria, que estão intimamente ligados às organizações criminosas mundiais. Isto gera um círculo vicioso, em que os crimes no âmbito internacional tornam-se interdependentes.

No que diz respeito aos efeitos gerados pelas organizações criminosas que agem diretamente no Brasil, causando prejuízos imediatos ao país, Medeiros (2005, p. 32) expõe que:

No Brasil, o governo deixa de arrecadar cerca de $\mathrm{R} \$ 1,4$ bilhão por ano, somente com os carregamentos que chegam do Paraguai. O dinheiro movimentado pela máfia do cigarro, que gira em torno de $\mathrm{R} \$ 1,8$ bilhão, serve para o financiamento do tráfico de drogas e o contrabando de outros produtos falsificados.

Nessa perspectiva, observa-se que os crimes no comércio internacional estão interligados, e muitas vezes coexistem numa mesma situação, como neste caso exemplificado, que se observa a prática de contrabando e descaminho. Assim, os efeitos gerados pelos crimes no comércio internacional são comumente parecidos, justificando esta análise conjunta das consequiências resultantes das inúmeras práticas ilícitas internacionais.

Outro efeito gerado pela prática desses crimes no comércio internacional é a diminuição da soberania nacional, visto que ela é ameaçada pelo fato do Estado não conseguir enfrentar sozinho a questão dos crimes dentro de seu território. Assim, o Estado necessita da intervenção de outro país, formando uma cooperação tática e política para solucionar ou diminuir a ocorrência desses crimes. (MINGST, 2009)

No que se refere ao âmbito político dos Estados, nota-se outra causa para a diminuição da soberania dos Estados, ao passo que o controle e punição dos transgressores ainda estão 
longe do ideal, gerando impunidade e fomentando o crescimento dessas práticas ilícitas. Assim, a não reprovabilidade dessas condutas geram outros sistemas ilegais que lucram com essas atividades, como os já citados crimes organizados, que ameaçam diretamente a soberania nacional, ao passo que não respeitam as leis e tampouco se submetem às políticas de repressão a crimes, além de aumentarem em sobremaneira os índices de criminalidade do Estado. (NAÍM, 2006)

Os crimes no comércio internacional também fomentam a corrupção estatal, visto que para se manter a máquina criminosa, normalmente há alguma espécie de corrupção nas esferas do Poder, seja no Legislativo, Executivo e Judiciário, a fim de prover os mecanismos facilitadores necessários para a ocorrência destes crimes. Isto ocorre para que se possa cometer o próprio crime, como a evasão de divisas e o descaminho, ou para se realizar outras ações fraudulentas para se chegar ao resultado final. Fato comprovador disto é o de casos que envolvem os próprios agentes repressores na realização de atos criminosos em troca de algum benefício ou favorecimento pessoal.

Outro efeito pertinente causado por essas práticas comerciais ilícitas é o de possível alteração das taxas de câmbio e de juros, especialmente no que se trata do crime de evasão de divisas. Assim, segundo Lima (2005):

Esse dinheiro afeta as taxas de câmbio e de juros, provocando instabilidade dos mercados. Pode ainda alterar, artificialmente, os rumos da movimentação de capital no mercado mobiliário, causando comportamentos extremos e grande volatilidade nos preços e nos volumes negociados.

Assim, o autor retrata que a prática ilícita no comercial internacional enseja prejuízos também ao cenário do mercado mundial, em que devido a um possível aumento na demanda por um determinado produto ou serviço, cause uma alteração nas taxas de câmbio e de juros do país, além de influenciar também nos preços negociados. Todos esses fatores influenciáveis pela prática desses atos ilícitos irão repercutir na própria sociedade, que poderá ter que pagar mais por aquele produto ou serviço que consumia por um preço mais baixo.

Há ainda que se discutir acerca da fuga de investidores nacionais e internacionais, como outro efeito evidente da prática dos atos ilícitos aqui debatidos. Esses crimes provocam uma concorrência desleal entre o produto fabricado no país, que segue toda a regulamentação imposta, e o produto que entra ilegalmente no país, que por não seguir as mesmas normas impostas pelo mercado nacional, adentram com o preço muito inferior ao produto nacional. Isto gera uma competição desleal, em que provavelmente a indústria nacional não se sinta atraída e estimulada a investir neste mercado sob estas condições, sendo lógica a fuga por outros mercados mais atrativos e que lhe forneçam mais garantias quanto a sua produção.

O Brasil, como uma potência econômica cada vez mais evidente para a comunidade internacional, pode sofrer retaliações por parte dos outros governos, já que existe uma comoção mundial para o combate destes crimes internacionais, e o país se apresenta muito aquém do que poderia estar, de acordo com opiniões estrangeiras. Como foram feitos vários acordos sobre o tema, quando o Brasil não consegue atingir alguma meta prevista, fica sujeito a medidas restritivas no comércio internacional, a fim de dar uma punição ao país. 
No entanto, atualmente deixou-se de lado um pouco o aspecto punitivo para forçar uma determinada ação repressora de um país contra as práticas comerciais ilegais. Passou-se a adotar uma postura diferente, em há mais cooperação entre países, em que ambos possam contribuir com as experiências de cada um e com as medidas eficazes já utilizadas em seus territórios. No que se refere ao combate à pirataria como uma cooperação entre os Estados Unidos e o Brasil, o então procurador-geral de Justiça dos EUA disse, na reportagem feita por Passos (2010):

Creio que, como dois líderes em tecnologia, dois líderes com uma grande base industrial, e dois líderes com setores de propriedade intelectual muito vibrantes, os EUA e o Brasil têm a obrigação de liderar nessa região, se não no mundo. $O$ que estamos tentando fazer é desenvolver mecanismos que nos permitam trabalhar com os parceiros brasileiros para liderar esse esforço

Por fim, há de se discutir um dos principais problemas causados pelos crimes no comércio internacional que é o da interferência negativa na balança comercial brasileira, visto que com um menor investimento na indústria nacional, acompanhada de um maior índice de desemprego, e da própria falência destes estabelecimentos, percebe-se também uma conseqüente diminuição das exportações brasileiras. Assim, se algo não for feito ao contrário, a tendência é dos brasileiros consumirem mais produtos provenientes do exterior, sejam produtos com entrada legal ou ilegal, do que os produtos nacionais, já que estes teriam oferta menor e teriam preços menos competitivos em relação aos estrangeiros.

\section{CONSIDERAÇÕES FINAIS}

A partir do estudo realizado sobre a temática dos crimes no comércio internacional, feito através de uma pesquisa exploratória descritiva e de uma análise de dados estatísticos, constatou-se a existência de impactos sociais e econômicos incidentes no Brasil. Estas práticas são extremamente prejudiciais à economia nacional, às relações comerciais com os demais países, e traz danos para toda a sociedade brasileira.

Apesar de não existirem dados estatísticos que demonstrem os prejuízos causados conjuntamente por todas as práticas ilícitas comerciais discutidas neste estudo, pôde-se inferir o enorme prejuízo causado por esses delitos em toda a sociedade. Dentre os prejuízos gerados pelo contrabando, descaminho, dumping, evasão de divisas e pirataria, destacou-se, especialmente nos crimes da pirataria e contrabando, danos relativos à saúde $\mathrm{e}$ segurança das pessoas. Para tanto, foi demonstrado que as mercadorias ilícitas não passam por nenhum controle para entrar no país, causando danos, muitas vezes irreversíveis, aos consumidores desses produtos. Neste quesito contatou-se o importante papel dos órgãos fiscalizadores, como o INMETRO e ANVISA, ao passo que os trabalhos realizados por esses organismos, juntamente com os demais, previnem e reprimem a prática desses atos comerciais ilícitos.

Com relação a essa questão de repressão e prevenção dos crimes no comércio internacional, evidencia-se o principal organismo nacional atuante nesta área, que é a Receita Federal Brasileira. No entanto, constatou-se que este órgão necessita de melhorias quanto a sua estruturação interna, como o oferecimento de novos cargos e o investimento em materiais utilizados pelos profissionais deste órgão. Destacou-se também, no decorrer deste estudo, o trabalho feito pelo FNCP, CNCP, Decom, INTERPOL e ICC, trabalho este que soma ao esforço internacional de combate a estes delitos. 
Quanto aos fatores intervenientes, verificou-se que um dos principais facilitadores para a ocorrência dos crimes no comércio exterior, é o extenso território nacional, que dificulta a ação dos profissionais da área. Isto se deve ao fato de que em alguns casos se torna inviável a realização de fiscalizações em toda a extensão da fronteiras brasileiras, abrindo espaço para a prática desses ilícitos.

Outros fatores intervenientes foram elencados neste estudo, de forma a contribuir essencialmente para o desenvolvimento dessas práticas ilícitas no país, tais como: incidência de alta carga tributária sobre os produtos legais, que onera demasiadamente os produtos legalizados, abrindo espaço para os produtos ilegais de estabelecerem no mercado nacional; aceitação social dessas condutas, que muitas vezes são consideradas eticamente irrelevantes; falta de investimentos públicos; e escassez de políticas públicas para informar a sociedade acerca dos efeitos produzidos por esses crimes. Estes fatores intervenientes se mostram interligados, ao passo que se necessita de uma ação conjunta de organismos nacionais e internacionais para reverter o quadro existente, que é o da alta incidência destas práticas ilícitas, com a tendência de crescimento, tendo em vista que a demanda por esses produtos é crescente.

Assim, através das pesquisas bibliográficas realizadas, investigações feitas com os profissionais atuantes na área, bem como as consultas feitas a sítios na internet, foi constatada as reais implicações desses crimes na sociedade. Dentre as implicações na sociedade destaca-se ainda a queda na arrecadação fiscal, que diminui as verbas públicas disponíveis para o investimento na própria sociedade; a concorrência desleal causada por essas mercadorias desleais, gerando prejuízos para a indústria nacional, aumentando os índices de desemprego e podendo interferir nos resultados da balança comercial brasileira.

Os lucros obtidos com a ocorrência dos crimes no comércio internacional também fomentam o crime organizado, expandindo, desta forma, a criminalidade transnacional. Estas organizações criminosas, por não seguirem as ordens impostas pelo Estado, desregulamentam toda a sociedade, ao passo que podem afetar a soberania do Estado, bem como aumentar os índices de criminalidade no país.

Desta forma, ficou constatado que os crimes no comércio internacional interferem direta ou indiretamente em toda a economia e sociedade brasileira, evidenciando o importante papel dos órgãos intervenientes para a prevenção e o combate destes crimes.

Há de se destacar também, a difusão de informações deste assunto para a população em geral, em que boa parte desconhece os efeitos gerados por essas práticas e outra parte considera os efeitos gerados como sendo irrelevantes para a sua realidade. Observa-se, assim, a falta de investimento governamental e privado neste quesito importante para a prevenção dos crimes.

\section{REFERÊNCIAS}

1. AGÊNCIA NACIONAL DE VIGILÂNCIA SANITÁRIA. Brasília: ANVISA, 2010. Disponível em: <www.anvisa.gov.br>. Acesso em: 8 mar. 2010.

2. ASSOCIAÇÃO BRASILEIRA DOS PRODUTORES DE DISCOS. Evolução da Pirataria de CDs no Brasil. [S.l.: ABPD, 2006].Disponível em: <http://www.abpd.org.br/pirataria_dados.asp>. Acesso em: 20 abr. 2010. 
3. BAER, Werner. A economia brasileira. 2. ed. São Paulo: Nobel, 2002.

4. BARBOSA, Paulo Sérgio. Competindo no comércio internacional: uma visão geral do Processo de Exportação. São Paulo: Aduaneiras, 2004.

5. BRASIL. Congresso. Câmara dos Deputados. Comissão Parlamentar de Inquérito da Pirataria. CPI da Pirataria: relatório. Brasília: Câmara dos Deputados, Coordenação de Publicações, 2004.

6. BRASIL. MINISTÉRIO DA JUSTIÇA. Ações MJ: 2007-2009. Brasília: MJ, 2009. Disponível em:

<http://portal.mj.gov.br/services/DocumentManagement/FileDownload.EZTSvc.asp? DocumentID=\%7B5123BE7B-025F-4F64-B19B-

AB45EE6BB3FB\%7D\&ServiceInstUID=\%7BB78EA6CB-3FB8-4814-AEF631787003C745\%7D>. Acesso em: 14 maio 2010, 20:14:00.

7. BRASIL. MINISTÉRIO DO DESENVOLVIMENTO, INDÚSTRIA E COMÉRCIO EXTERIOR. Circular SECEX n 21, de 08 de abril de 1996. Brasília: MDIC, 1996. Disponível em:

<http://www.desenvolvimento.gov.br/arquivos/dwnl_1196966353.pdf>. Acesso 28 mar. 2010.

8. _ Evolução das Exportações Brasileiras. Brasília: Brasil Exportador, 2009. Disponível em: <http://www.mdic.gov.br/arquivos/dwnl_1268057181.pdf>. Acesso em 12 maio 2010, 17:46:00.

9. Ministério divulga dados de exportação brasileira por zona produtora. Brasília: MDIC, 2009. Disponível em:

<http://www.mdic.gov.br/sitio/interna/noticia.php?area=5\&noticia=7965>. Acesso em: 30 maio 2010.

10. BRASIL. MINISTÉRIO DO DESENVOLVIMENTO, INDÚSTRIA E COMÉRCIO EXTERIOR. Conselho Nacional de Combate à Pirataria e delitos contra a Propriedade Intelectual. Combate à Pirataria. Brasília: CNCP, 2007. Disponível em:

<http://portal.mj.gov.br/combatepirataria/data/Pages/MJ7111CEC5PTBRIE.htm>. Acesso em 11 mar. 2010.

11. Mapa estratégico do Conselho Nacional de Combate à Pirataria 2008/2012. Brasília: CNCP, 2007. Disponível em:

<http://portal.mj.gov.br/combatepirataria/data/documents/storedDocuments/\%7B334 263AD-A534-4B0E-AD1D-363427828AB4\%7D/\%7B7EDD84C6-9F45-49E8-

A66E-07644179A24E\%7D/mapa.jpg>. Acesso em: 14 abr. 2010, 14:55:00

12. BRASIL. MINISTÉRIO DO DESENVOLVIMENTO, INDÚSTRIA E COMÉRCIO EXTERIOR. DEPARTAMENTO DE DEFESA COMERCIAL. Brasília: DECOM, 2010. Disponível em:

$<$ http://www.mdic.gov.br/sitio/interna/interna.php?area=5\&menu=228>. Acesso em 13 mar. 2010.

13. RELATÓRIO DECOM No 11 - 2007. Brasília: DECOM, 2007. Disponível em: < http://www.mdic.gov.br/arquivos/dwnl_1221598012.pdf>. Acesso em: 10 mar. 2010, 18:10:00. 
14. . RELATÓRIO DECOM No 12 - 2008. Brasília: DECOM, 2008. Disponível em: < http://www.mdic.gov.br/arquivos/dwnl_1242396716.pdf>. Acesso em: 10 mar. 2010, 18:59:00.

15. BRASIL. PRESIDÊNCIA DA REPÚBLICA. Constituição da República Federativa do Brasil de 1988. Disponível em:

<http://www.planalto.gov.br/ccivil_03/constituicao/constitui\%C3\%A7ao.htm>. Acesso em: 10 mar. 2010.

16. Decreto no $\mathbf{1}$. Incorpora os Resultados da Rodada Uruguai de Negociações Comerciais Multilaterais do GATT. Brasília: Planalto, 1994. Disponível em: <http://www.planalto.gov.br/ccivil_03/decreto/Antigos/D1355.htm>. Acesso em: 08 fev. 2010.

$17 . \quad$ Decreto $\mathbf{n}^{\mathbf{0}} \mathbf{1 . 6 0 2}$, de 23 de agosto de 1995. Regulamenta as normas que disciplinam os procedimentos administrativos, relativos à aplicação de mediadas antidumping. Brasília: Planalto, 1995. Disponível em:

<http://www.planalto.gov.br/ccivil_03/decreto/1995/D1602.htm>. Acesso em: 02 abr. 2010.

18.

Decreto no 2.781, de 14 de setembro de 1998. Institui o Programa Nacional de Combate ao Contrabando e ao Descaminho. Brasília: Planalto, 1998. Brasília: Planalto, 1998. Disponível em: <https://www.planalto.gov.br/ccivil_03/decreto/d2781.htm>. Acesso em: 14 fev. 2010 .

19. _ Decreto no 6.759, de 5 de fevereiro de 2009. Regulamenta a administração das atividades aduaneiras, e a fiscalização, o controle e a tributação das operações de comércio exterior. Brasília: Planalto, 2009. Disponível em: $<$ http://www.planalto.gov.br/ccivil_03/_Ato20072010/2009/Decreto/D6759.htm\#art820>. Acesso em: 06 fev. 2010.

20. __ Decreto-lei $\mathbf{n}^{\mathbf{0}}$ 37, de 18 de novembro de 1966. Dispõe sobre o imposto de importação, reorganiza os serviços aduaneiros e dá outras providências. Brasília: Planalto, 1966. Disponível em: <http://www.planalto.gov.br/ccivil/decretolei/Del0037.htm>. Acesso em: 27 abr. 2010.

21.

Decreto-lei $\mathbf{n}^{\mathbf{0}} \mathbf{2 . 8 4 8}$, de 7 de dezembro de 1940. Decreta a Lei do Código Penal. Brasília: Planalto, 1940. Disponível em: <http://www.planalto.gov.br/ccivil/decreto-lei/del2848.htm>. Acesso em: 20 abr. 2010 .

22. Lei $\mathbf{n}^{\mathbf{0}} \mathbf{7 . 4 9 2}$, de 16 de junho de 1986. Define os crimes contra o sistema financeiro nacional, e dá outras providências. Brasília: Planalto, 1986. Disponível em: <http://www.planalto.gov.br/ccivil/leis/L7492.htm>. Acesso em: 05 mar. 2010.

23.

Lei $\mathbf{n}^{\circ}$ 8.137, de 27 de dezembro de 1990. Define crimes contra a ordem tributária, econômica e contra as relações de consumo, e dá outras providências. Brasília: Planalto, 1990. Disponível em: < http://www.planalto.gov.br/ccivil/leis/L8137.htm>. Acesso em 18 mar. 2010.

24. L Lei no 9.019, de 30 de março de 1995. Dispõe sobre a aplicação dos direitos previstos no Acordo Antidumping e no Acordo de Subsídios e Direitos 
Compensatórios, e dá outras providências. Brasília: Planalto, 1995. Disponível em: <http://www.planalto.gov.br/ccivil_03/Leis/L9019.htm>. Acesso em: 10 abr. 2010.

25.

Lei $\mathbf{n}^{\circ}$ 9.279, de 14 de maio de 1996. Regula direitos e obrigações relativos

à propriedade industrial. Brasília: Planalto, 1996. Disponível em:

<http://www.planalto.gov.br/ccivil_03/Leis/L9279.htm>. Acesso em: 13 jan. 2010.

26.

tributária federal, as contribuições para a seguridade social, o processo

administrativo de consulta e dá outras providências. Brasília: Planalto, 1996.

Disponível em: <http://www.planalto.gov.br/ccivil_03/Leis/L9430.htm>. Acesso em:

15 jan. 2010.

27. BRASIL. SECRETARIA DE COMÉRCIO EXTERIOR /MINISTÉRIO DO

DESENVOLVIMENTO, INDÚSTRIA E COMÉRCIO EXTERIOR. Balança

comercial brasileira: dados consolidados. Brasília: Brasil Exportador, 2005.

Disponível em:

<http://www.desenvolvimento.gov.br/arquivo/secex/balanca/balcombrasileira/compa cta/cartilhabalanca2005.pdf>. Acesso em: 15 maio 2010.

28. Boletim informativo da FNCP. Disponível em

<http://www.forumcontrapirataria.org/v1/abf.asp?idP=411>. Acesso em: 20 mar.

2010. 17:45:00.

29. BONAT, Luiz Antonio. Crimes Relacionados com o Comércio Exterior. In:

FREITAS, Vladimir Passos (Coordenador). Importação e exportação no Direito

Brasileiro. São Paulo: Revista dos Tribunais, 2004. p. 340 - 411.

30. CENTRO INTERNACIONAL DE NEGÓCIOS DA PARAÍBA. Brasil já é o $\mathbf{2 3}^{\circ}$ maior exportador do mundo. João Pessoa: CIN, 2006. Disponível em:

<http://www.cinpb.org.br/noticias/integra.jsp?idNoticia=20>. Acesso em: 15 mar. 2010, 18:39:00.

31. COSTA, Gilberto. Pobres pagam mais impostos no Brasil. Agência Brasil. São Paulo: Folha de Alphaville Online, 2009. Disponível em:

<http://www.folhadealphaville.com.br/artigo/?id=6565>. Acesso em: 28 abr. 2010, 19:00:00.

32. DEPARTAMENTO DE POLÍCIA FEDERAL. Relatório Anual de Atividades: 2008. Brasília, 2008.

33. INSTITUTO BRASILEIRO DE ÉTICA CONCORRENCIAL. São Paulo: ETCO, 2010. Disponível em: < http://www.etco.org.br/>. Acesso em: 24 mar. 2010.

34. FEDERAÇÃO DO COMÉRCIO DO ESTADO DO RIO DE JANEIRO. O consumo de produtos piratas no Brasil. Rio de Janeiro: Ipso, 2007.

35. FÓRUM NACIONAL CONTRA A PIRATARIA E A ILEGALIDADE. (FNCP). Disponível em: < http://www.forumcontrapirataria.org/v1/default.asp>. Acesso em 18 mar. 2010, 15:19:00.

36. FRANCA, Luiz Henrique Behrens. A repressão ao contrabando e ao descaminho. Belo Horizonte: CONAF, 2008. Disponível em:

<http://www2.unafisco.org.br/institucional/conaf/conaf2008/CD/download/tese/I_A

\%20repressao_LuizHenrique.pdf $>$. Acesso em 14 abr. 2010, 13:24:00 
37. FRANCO, Ana Paula Cardoso. Dumping e os mecanismos jurídicos de defesa empresarial. Franca: UNESP, 2005. Disponível em:

<http://www.franca.unesp.br/Ana_Paula_Cardoso_Franco.pdf $>$. Acesso em: 19 maio 2010 .

38. GIAMBIAGI, Fábio; AVERBUG, André. A crise brasileira de 1998/1999 - origens e consequencias. Rio de Janeiro: BNDES, 2000. Disponível em:

<http://www.bndes.gov.br/SiteBNDES/export/sites/default/bndes_pt/Galerias/Arquiv os/conhecimento/td/Td-77.pdf>. Acesso em: 02 jun. 2010.

39. GIL, Antonio Carlos. Como elaborar projetos de pesquisa. 4. ed. São Paulo: Atlas, 2002.

40. HARTUNG, Douglas S. Negócios Internacionais. Rio de Janeiro: Qualitymark, 2002.

41. HOUAISS, Antônio; VILLAR, Mauro de Salles. Dicionário Houaiss da Língua Portuguesa. Rio de Janeiro: Objetiva, 2001.

42. IDCID (Instituto de Direito do Comércio Internacional e Desenvolvimento). Disponível em: < http://www.idcid.org.br/>. Acesso em: 10 mar. 2010, 19:00:00.

43. INSTITUTO NACIONAL DE METROLOGIA, NORMALIZAÇÃO E QUALIDADE INDUSTRIAL (INMETRO). Disponível em: < http://www.inmetro.gov.br/>. Acesso em: 20 mar. 2010, 23:18:00.

44. INSTITUTO NACIONAL DE PROPRIEDADE INDUSTRIAL. INPI e FIFA se unem para combater a pirataria. Rio de Janeiro: INPI, 2010. Disponível em: <http://www.inpi.gov.br/noticias/inpi-e-fifa-se-unem-para-combater-a-pirataria>. Acesso em: 10 maio 2010.

45. INTERNATIONAL CHAMBER OF COMMERCE. Paris: ICC, 2010. Disponível em: <http://www.iccwbo.org/>. Acesso em: 10 mar. 2010.

46. INTERNATIONAL CRIMINAL POLICE ORGANIZATION. Lyon: INTERPOL, 2010. Disponível em: < http://www.interpol.int/>. Acesso em 21 mar. 2010, 18:49:00.

47. LEMOS, Dagoberto da Silva; BURG, Alfonso; CALIL Rogério Said. Fortalecer a aduana para proteger o país: criação do cargo auxiliar aduaneiro. Rio de Janeiro: CONAF, 2008. Disponível em:

<http://www2.unafisco.org.br/institucional/conaf/conaf2008/CD/download/tese/I_Fo rtaleceraAduana_DagobertoSilva.pdf $>$. Acesso em: 28 mar. 2010.

48. LIMA, Sérgio Luiz Messias de. A Receita Federal do Brasil e a prevenção à lavagem de dinheiro e ao financiamento do terrorismo. Brasília: AFRFB, 2005. Disponível em:

<http://www.esaf.fazenda.gov.br/esafsite/premios/schontag/Monografias_premiadas _arquivos/monografia/monografias\%204\%C2\%BA/MH2\%20S\%C3\%89RGIO\%20L UIZ\%20MESSIAS\%20DE\%20LIMA.pdf>. Acesso em: 18 abr. 2010.

49. LUZ, Rodrigo. Ponto dos Concursos: preparando com objetividade. Brasília: Ponto dos Concursos, 2010. Disponível em: <http://www.pontodosconcursos.com.br/>. Acesso em: 1 jun. 2010, 22:20:00.

50. LUZ, Rodrigo Teixeira. Relações econômicas internacionais: teoria e questões. Rio de Janeiro: Elsevier, 2006. 
51. MAZUR, Bianca de Freitas. Os tipos de contrabando e descaminho como capítulo do direito penal: análise de seus aspectos, elementos e características. Curitiba: UFPR, 2010. Disponível em:

<http://dspace.c3sl.ufpr.br:8080/dspace/bitstream/1884/731/2/mazur,\%20bianca1.pdf >. Acesso em: 24 nov. de 2010.

52. MEDEIROS, Luiz Antonio de. CPI da Pirataria: os segredos do contrabando e da falsificação no Brasil. São Paulo: Geração Editorial, 2005.

53. MINGST, Karen A. Princípios de Relações Internacionais. Tradução de Arlete Simille Marques. Rio de Janeiro: Elsevier, 2009.

54. NAÍM, Moisés. Ilícito: o ataque da pirataria, da lavagem de dinheiro e do tráfego a economia global. Tradução de Sérgio Lopes. Rio de Janeiro: Jorge Zahar, 2006.

55. NERI, Isabela Luciana Araújo. Mercado Fonográfico: uma análise do surgimento do mercado paralelo no município de Recife. Recife: UNICAP, 2005. Disponível em: < http://www.unicap.br/ccs/20051/isabela.pdf>. Acesso em 10 maio 2010.

56. PASSOS, José Meirelles. EUA mudam estratégia e querem parceria com Brasil para combater pirataria. Rio de Janeiro: O Globo, 2010. Disponível em: <http://oglobo.globo.com/economia/mat/2010/02/24/eua-mudam-estrategia-queremparceria-com-brasil-para-combater-pirataria-915930033.asp>. Acesso em: 30 maio 2010 .

57. PEDROZA, Carla. Dica Jurídica: Eis o novo alvo dos piratas Contrabandeada da China, uma carga de películas para vidros de automóveis, avaliada em $\mathrm{R} \$ 1$ milhão, foi apreendida ontem pela Polícia Federal.São Paulo: ABRAWF, 2010. Disponível em: <http://www.abrawf.com.br/jornal/06-2002/dica_juridica.htm>. Acesso em: 14 maio 2010 .

58. PERUCHIN, Vitor Antonio Guazzelli. O crime de evasão de divisas: dificuldades definitoriais e de controle. Porto Alegre: PUCRS, 2006. Disponível em:

$<$ http://tede.pucrs.br/tde_busca/arquivo.php?codArquivo=297>. Acesso em: 28 maio 2010 .

59. Pirataria: Tô Fora! Disponível em: <http://www.piratatofora.com.br/>. Brasília: SINDIRECEITA, 2010. Acesso em: 20 nov. 2009, 13:00:00.

60. Receita Federal. Disponível em: <http://www.receita.fazenda.gov.br/>. Brasília: RFB, 2010. Acesso em: 20 nov. 2010, 18:28:00.

61. _. Preços de Transferência. Disponível em: < http://www.receita.fazenda.gov.br/pessoajuridica/dipj/2005/pergresp2005/pr672a733 .htm>. Acesso em 20 mar. 2010, 21:15:00.

62. Relatório Pesquisa IBOPE- Instituto Brasileiro de Opinião Pública e Estatística-, 2007. A Câmara de Cómercio dos E.U.A e o Conselho Empresarial Brasil Estados Unidos (seção americana) em parceria com a ANGARDI - Associação Nacional pela Garantia dos Direitos Intelectuais apresentam a $3^{\text {a }}$ edição da pesquisa realizada com a metodologia IBOPE sobre o impacto da pirataria no setor de consumo. Disponível em: <http://www.firjan.org.br/lumis/portal/file/fileDownload.jsp?fileId=2C908CE9215B 0DC4012163A14F37666B>. Acesso em 14maio 2010, 18:45:00.

63. RIBEIRO, Letícia Parente. Zonas de Fronteira Internacionais na atualidade: uma discussão. [S.1.: s.n, 2010]. Disponível em: 
<http://www.observatorioseguranca.org/pdf/01\%20(27).pdf>. Acesso em: $06 \mathrm{dez}$. 2010 .

64. RIBEIRO JR, Amaury e FILGUEIRAS, Sônia. Ralo da impunidade: Relatório que a PF esconde aponta que políticos, contrabandistas e traficantes tiraram do País US\$ 30 bilhões em três anos. Istoé Independente: Foz do Iguaçu, nov.2009. Disponível em:

<http://www.istoe.com.br/reportagens/16610_RALO+DA+IMPUNIDADE?pathIma gens $=\&$ path $=\&$ actualArea $=$ internalPage $>$. Acesso em: 27 maio 2010.

65. SALVO, Mauro. A Economia do Crime e da Cultura: uma aplicação ao mercado de obras de arte roubadas e as perspectivas dos agentes de Porto Alegre. Disponível em: <http://www.pucrs.br/eventos/eeg/trabalhos/historia-sessao1-1.doc>. Acesso em: 06 dez. 2009.

66. Sindicato Nacional da Carreira Auditoria da Receita Federal do Brasil. $1^{\text {a }}$ Curso de Capacitação: Mauro de Brito defende parceria para o combate à pirataria. Brasília: SINDRECEITA, 2010. Disponível em:

<http://www.sindireceita.org.br/index.php?ID_MATERIA=7601>. Acesso em: 20 mar. 2010, 23:00:00.

67. _. Por uma tributação mais justa. Brasília: SINDRECEITA, 2010. Disponível em:

<http://www2.unafisco.org.br/noticias/boletins/2008/setembro/anexo_2681_informe. pdf>. Acesso em: 19 abr. 2010.

68. SOUZA, Nali de Jesus de. Curso de Economia. 2. ed. São Paulo: Atlas, 2003.

69. SCHILLING, Voltaire. Globalização, ontem e hoje. Disponível em: <http://educaterra.terra.com.br/voltaire/atualidade/globalizacao3.htm>. Acesso em: 04 maio 2010.

70. SWARTZ, Bruce. Questões globais: coibição do crime internacional. Como ajudar o Mundo a Combater o Crime Internacional. Publicação Eletrônica do Departamento de Estado dos Estados Unidos, 2001. Disponível em: <http://www.scribd.com/doc/7392941/Coibicao-Do-Crime-Internacional>. Acesso em: 10 maio 2010.

71. TOLEDO, Francisco de Assis. Princípios básicos de direito penal. São Paulo: Saraiva, 1994.

72. VISMONA, Edson Luiz. Todos perdem com a pirataria. São Paulo: FNCP, 2010. Disponível em: <http://www.forumcontrapirataria.org/v1/abf.asp?idP=611>. Acesso em: 14 maio 2010.

73. WIKIPEDIA. Escândalo do Banestado. [S.1.: s.n., 2010]. Disponível em: <http://pt.wikipedia.org/wiki/Esc\%C3\%A2ndalo_do_Banestado>. Acesso em: 10 mai. 2010. 